Management Sciences for Health

Afghanistan Health Sector Support Project

DEMOGRAPHIC AND HEALTH HOUSEHOLD SURVEY IN AFGHANISTAN

WARDAK PROVINCE

Youssef Tawfik, M.D., M.P.H.

March, 1991.

Field Supervisors:

Omar Bahaand

Bacha Saleh

Waheedullah

Funded by:

The United States Agency for

International Development

Cooperative Agreement No. 306-0203-A-00-6014-00

Amendment Nos. 001-009 


\section{TABLE OF CONTENTS}

I. INTRODUCTION $\ldots \ldots \ldots \ldots \ldots \ldots \ldots \ldots \ldots \ldots \ldots \ldots \ldots \ldots \ldots \ldots$

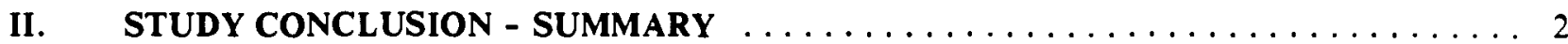

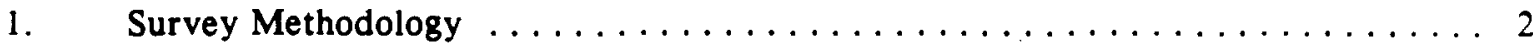

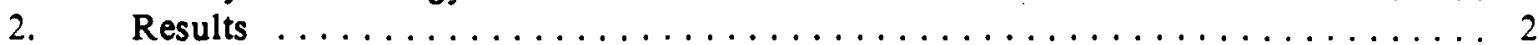

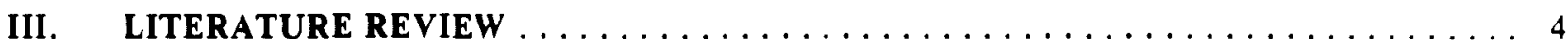

1. A Health Survey of Three Provinces of Afghanistan, Ministry of Public Health and Management Sciences for Health, $1976 \ldots \ldots \ldots \ldots \ldots \ldots \ldots \ldots \ldots \ldots \ldots$

2. Health and Disease in Rural Afghanistan, Alfred Buck, 1972. . . . . . . . 4

IV. OBJECTIVES OF THE CURRENT SURVEY (1990) $\ldots \ldots \ldots \ldots \ldots \ldots$

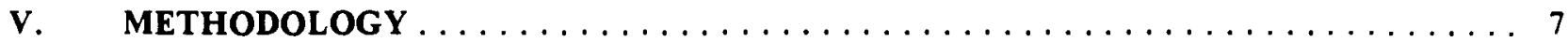

1. Province Selection and Sample Size $\ldots \ldots \ldots \ldots \ldots \ldots \ldots \ldots \ldots \ldots \ldots$

2. Field Supervisors and Interviewers $\ldots \ldots \ldots \ldots \ldots \ldots \ldots \ldots \ldots \ldots \ldots \ldots$

3. District, Village and Household Selection $\ldots \ldots \ldots \ldots \ldots \ldots \ldots \ldots \ldots \ldots \ldots$

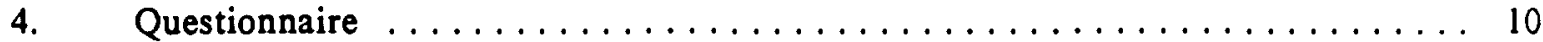

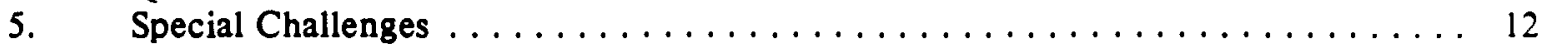

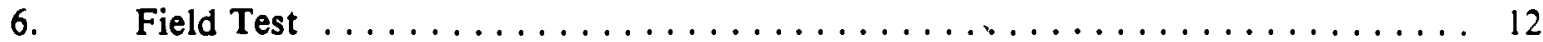

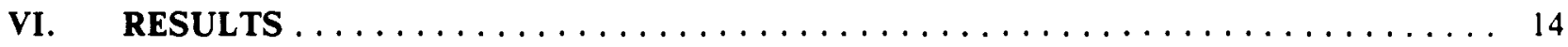

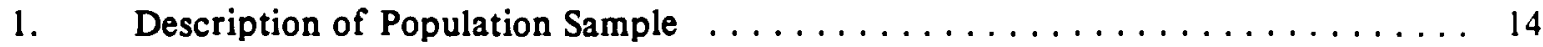

2. Morbidity Pattern, Source of Consultation and Expenditure on Health Services . 17

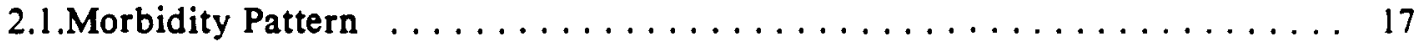

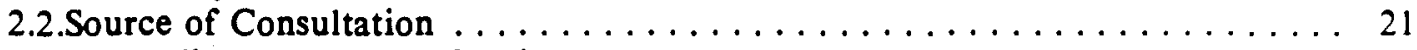

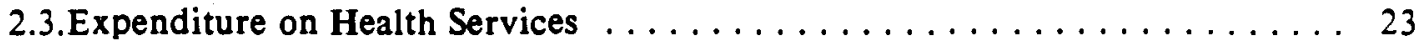

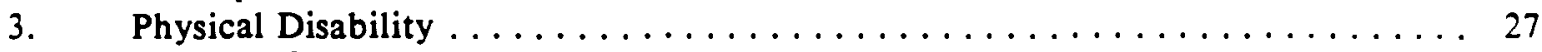

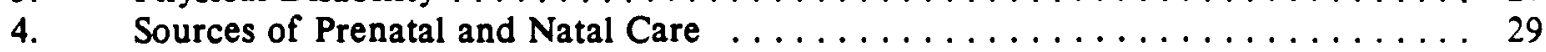

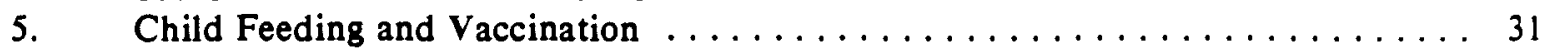

6. Mortality ................................ 31

ANNEX I: $\quad$ Questionnaire Forms $\ldots \ldots \ldots \ldots \ldots \ldots \ldots \ldots \ldots \ldots \ldots \ldots \ldots$ 


\section{LIST OF TABLES}

Table 1.

Table 2.

Table 3.

Table 4.

Table 5.

Table 6.

Table 7.

Table 8.

Table 9.

Table 10.

Table 11.

Table 12.

Sample Size and Interviewers by Household Survey . . . . . . . . . . . 9

Number of Households by District and Village, Wardak Province . . . . . . . 11

Distribution of Respondents by Age and Sex ............... 14

Ability to Read and Write by Age and Sex for Population about 5 Years Old . . . 16

Years in School by Age Group and Sex for Over 5 Year Old Population . . . . . . 17

Occupation by Age Group for Males Over 5 Years Old $\ldots \ldots \ldots \ldots \ldots \ldots 18$

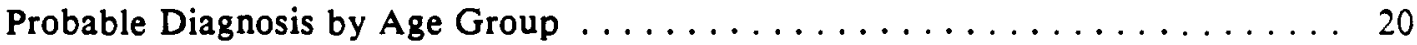

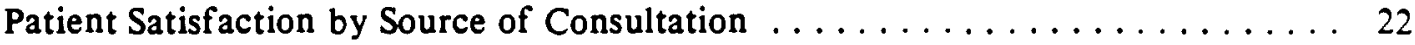

Deliveries in 12 Months by Age of Women ................... 29

Age When Food or Fluids Were Introduced for the First Time . . . . . . . . 32

Distribution of Children Under 5 Years Old Who Have Ever Been Vaccinated, By

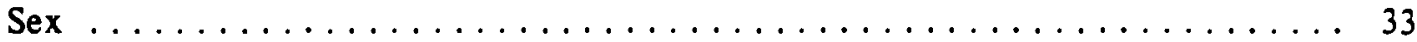

Presence of T.B. Scar Among Children Under 5 Years Old, By Sex . . . . . . . 33

\section{LIST OF FIGURES}

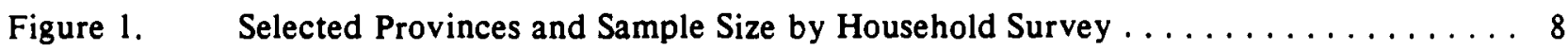

Figure 2. Distribution of Households by Number of Individuals $\ldots \ldots \ldots \ldots \ldots \ldots \ldots$

Figure 3. Age and Sex Distribution for Individuals $\ldots \ldots \ldots \ldots \ldots \ldots \ldots \ldots \ldots \ldots$

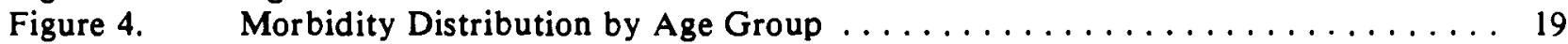

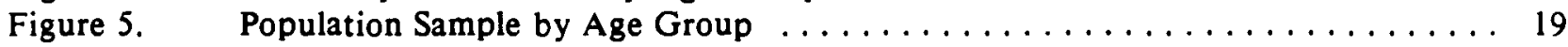

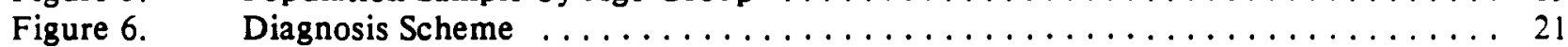

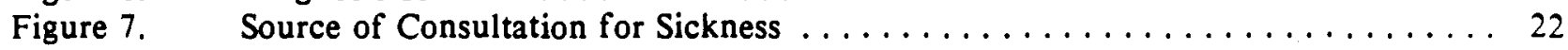

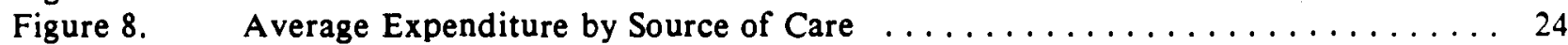

Figure 9. Proportion of Patients Who Paid for Care by Source of Care . . . . . . . . . 24

Figure 10. Average Expenditure by Source of Care for Patients Who Paid . . . . . . . . 25

Figure 11. Total Annual Income per Household $\ldots \ldots \ldots \ldots \ldots \ldots \ldots \ldots \ldots \ldots \ldots$

Figure 12. Average Annual Income per Household $\ldots \ldots \ldots \ldots \ldots \ldots \ldots \ldots \ldots \ldots$

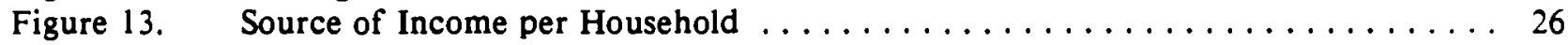

Figure 14. Average Expenditure on Sickness in Relation to Average Household Income . . . 27

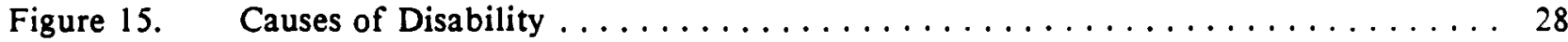

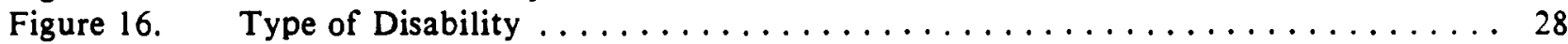

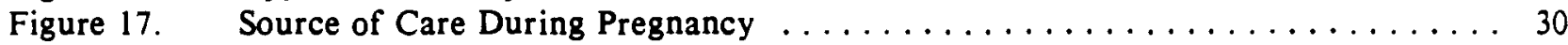

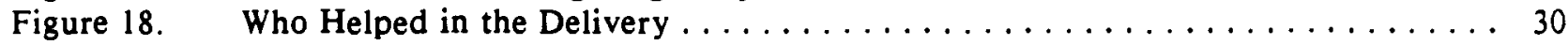

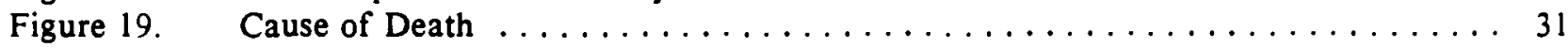




\section{INTRODUCTION}

The Afghanistan Health Sector Support Project began on October 1, 1986, through a three year Cooperative Agreement awarded to Management Sciences for Health (MSH) by the United States Agency for International Development (USAID). In February 1989 the Cooperative Agreement was amended extending the Project until December 31, 1992.

With the Project amendment, the original Project goal and purpose -- to expand and strengthen health services inside Afghanistan as rapidly as possible and to strengthen the capability of the Seven Party Alliance Health Committee (AHC) to plan, operate, and monitor an expanded health services system in Afghanistan -- were changed only slightly, giving more emphasis to civilian care, particularly to women and children, and increasing the focus on development of health services in organized areas.

To plan health services in Afghanistan and set priority programs, the Project found it necessary to conduct basic health surveys and operations research. The primary objective of such studies was to improve the quality, efficiency, coverage, and sustainability of the health services initiated by the project.

In preparing the cross border survey strategy, the following Peshawar based organizations were contacted: WHO, UNICEF, AVICEN, ACBAR, ARIC, CMC, ARC, UNHCR, IRC, MSF, Swedish committee, and Freedom Medicine.

The Project began the study process by identifying the health planning and management questions to be answered by cross-border surveys; conducting a literature review to determine what information was already available; determining the type, content and number of cross border surveys needed; preparing a prototype plan for survey logistics to determine the feasibility and cost of different survey options, as well as the potential constraints for obtaining reliable information; and, finally, preparing a draft survey schedule, including estimated financial and technical assistance requirements.

A list of research options was identified. Particularly valuable information to be derived from research included: a mortality profile; a morbidity profile; sources of health care and private health expenditure; the extent of physical disability in the population; a malaria survey; a tuberculosis study; a maternal health assessment study; an $\mathrm{MCH}$ human resources study; and, a malnutrition and feeding practice survey. Selecting which research option to start with was undertaken in priority order based on the importance of the research topic in relation to Project operations and the other research topics being considered, the logistical and technical feasibility of conducting the research, and the interest of the field staff in the research topic. With these criteria in mind, a suitable starting point was determined to be a household survey focusing on the extent of morbidity, mortality, and community expenditure on health services. 


\section{STUDY CONCLUSION - SUMMARY}

\section{Survey Methodology}

In order to guide the planning of health services in Afghanistan and set priority programs, the Afghanistan Health Sector Support Project decided to conduct a household survey to study the pattern of morbidity, mortality and expenditure on health services.

Takhar province in the north, Wardak province in the central mountainous part of the country, and Kandahar Province in the south were the selected survey sites. A total sample size of 900 households was decided. This report presents results of surveying 310 households in Wardak province. Takhar and Kandahar provinces are yet to be surveyed.

Carefully selected field supervisors were trained and sent to Wardak province where they worked with Basic Health Workers (BHWs) in 10 randomly selected villages in Sayed Abad, Chak Wardak and Jaghatoo districts.

The questionnaire forms and the survey strategy had been field tested in Konar province.

The study proved that household surveys can be conducted inside Afghanistan while the project is based in Pakistan, and selected BHWs can be utilized as surveyors if properly trained and supervised. If BHWs are selected as interviewers there is a possibility of introducing a certain bias to study results especially when evaluating the performance of health personnel in the community or the level of patient satisfaction with sources of health care. Also, using a male BHW limits access to information on women and neonatal health status in the community.

\section{Results}

On average there were 6 individuals per household. The sample included 942 males and 834 females with a sex ratio of 112.9 . The majority of households $(97.8 \%)$ were within $2 \mathrm{Km}$. from the nearest health facility.

Forty two percent of males and $1.6 \%$ of females above the age of 5 claimed that they could read and write.

Studying the morbidity pattern of the community revealed that females in the child bearing age -16 to 45 - were significantly more prone to getting sick than other age groups. This finding points out the importance of this age group from the health care point of view, especially in Afghanistan where most health workers are males.

Infectious diseases were on the top of the morbidity list for all age groups. As expected, acute respiratory infection and acute diarrhea were high. Dysentery cases were surprisingly very high, they counted for $11.2 \%$ of all cases. As feared, suspected T.B. and suspected malaria cases were high, they respectively formed $8.7 \%$ and $5.6 \%$ of cases.

The sources of health care which were most frequently called upon were: hospital or clinic; BHW; private doctor; shop for medicine (dokan); mullah; and pharmacy. The fact that hospitals or clinics were the most frequently used source of care reflects the relatively high concentration of such facilities in Wardak province. 
On average, for all sources of health care, each patient paid 1,324 Afghanis ( 1 SUS = 550 Afs.) in cash or in kind for health services. This amount is equivalent to 1.5 to 2 times the average household daily income. Almost two thirds of the expense was spent on drugs and the rest on transportation and consultation fee.

Private doctors and pharmacies were the most expensive sources of health care available to the community. The average cost of service from each or these two categories was more than 4,000 Afs. per case, or 5 times the average daily income per household.

Only $1.4 \%$ of the population suffered from physical disability. While this figure seems low in relation to the length and the the magnitude of the civil war, it is hard to draw a conclusion about whether the extent of disability is high or low without comparing this figure with figures from a population with no civil war or with communities suffered from a prolonged civil war.

Accidents, war injuries and musculoskeletal disorders including Poliomyelitis, respectively, were the most frequent causes of physical disability.

Investigating the sources of antenatal and natal care for women in the sample who had delivered in the 12 month prior to the interview revealed that only one third of women sought prenatal care. The important sources of prenatal care were dais (traditional birth attendants), mullahs (religious men respected in the community), and private doctors. Almost one fif th of women claimed that they have received a vaccination during their pregnancy. More than $90 \%$ of deliveries took place at home; the dai, the mother in law, and the mother were the main sources of help during delivery.

Sixty percent of all children under 5 years in the sample did not have any other foods or fluids, apart from milk, introduced in their meals by the age of 6 months. This late introduction of supplementary nutrition is likely to be one main cause of malnutrition among children.

A T.B. vaccination scar was detected in $56 \%$ of children and there was no significant difference between males and females.

In spite of the under reporting of mortality in general, and in particular for infants under 3 months old, children under 5 years comprised more than half the deaths. Diarrhea and acute respiratory infection caused almost half the deaths. 


\section{LITERATURE REVIEW}

Two previous household surveys were conducted in Afghanistan during the 1970s. One was carried out in 1976 by Management Sciences for Health and the Ministry of Public Health, and an earlier study was done in 1972 by Alfred Buck, of Johns Hopkins University. The following is a brief description of the methodology and significant results of the two studies.

1. A Health Survey of Three Provinces of Afghanistan, Ministry of Public Health and Management Sciences for Health, 1976.

Methodologv:

In a household survey 486 females and 237 males living in 17 villages of 3 different provinces, Ghazni, Helmand, Baghlan, were interviewed to obtain information about the health of their household and the steps they take when a member of that household is sick. Two established Basic Health Centers were chosen as focal points for village selection. Selection of BHCs was based on length of operation (and thus their potential impact on the community), as well as on the desire to achieve a representative variation of geographic, social, and economic conditions within each province. Village selection was accomplished by preparing grid maps of areas adjacent to the selected BHCs and by random selection of villages at $1 \mathrm{~km}, 10 \mathrm{~km}$, and $15 \mathrm{~km}$ from the health center. Within each village, household selection was done systematically, using prelists of households developed by a random start method. Depending on the size of the village, every second or third household on the prelist form was sampled. Within a household an attempt was made to interview an adult male and an adult female, preferably but not exclusively, a husband and a wife. Only one wife was interviewed per polygamous marriage. All interviews were carried out by trained male and female interviewers using separate interview forms for men and women that had been designed, pretested, and revised before the start of the survey.

\section{Results:}

The population surveyed included 3,483 individuals living in 486 households, i.e., an average of 7.17 persons per household. The mean number of rooms per household was 2.25 , with an average of 3.18 persons per room. Women of completed reproductive age, that is, over 45 , reported having given birth to 9.37 children on average, with 5.67 still living. The Crude Birth Rate was 48.5; Crude Death Rate was 24.2. Infant Mortality Rate was 157 . Almost $60 \%$ of all deaths in the preceding year were of children under 5 years.

Three types of illnesses, respiratory ailments, gastrointestinal illnesses, and fevers, accounted for 57 percent of all illnesses mentioned.

\section{Health and Disease in Rural Afghanistan, Alfred Buck, 1972.}

\section{Methodology:}

Four major areas of Afghanistan, considered representative of contrasts in the environment and of differences in the ethnic, religious and occupational characteristics of the population, were selected. These four areas were: 1) the central mountains of the Koh-i-Baba in the Province of Bamyan, 2) the northeastern central plain in the Province of Qunduz, 3) the agriculture development area of the 
Helmand Valley, near the city of Lashkargar, and 4) the foothills of the Paropamisus mountain range in the northeastern corner of Afghanistan in the Province of Herat. The villages finally selected were:

- Saidabad in the Province of Bayman, with predominantly Moghul population;

- Bulla Quchi in the Province of Qunduz, with Uzbek residents;

- Gawargin in the Helmand Valley, with Pushtoon population; and

- Korach in the Province of Herat, with Tajik and Sayed ethnic groups.

A complete map, listing every house, was prepared for each village. Thereafter, the population sample was defined by selecting either natural boundaries which enclosed the main part of the village or, if the village was very large, a representative segment. Excluded were small hamlets, individual houses or satellite communities which, although politically part of the village, were found scattered over a wide area. All houses in the sample area were given consecutive numbers which were listed on the map and painted on the houses. Finally, all families were visited by a census team which was composed of an Afghan male nurse and members of the local power structure.

The medical information of the study was obtained by five principal methods, health interviews, standardized physical examinations, laboratory tests, skin tests, and chest radiography. In addition, special ophthalmological examinations, including eye microscopy with slit lamp, funduscopy and conjunctival scraping for trachoma inclusion bodies, were carried out. The actual field procedures administered to, and requested from, all individuals in the study were: a health interview; a physical examination; four skin tests, two with different types of tuberculins (PPD-S and PPD-G), and one each with histoplasmin and Echinococcus granulosus antigen; a venipuncture for drawing approximately 10 milliliters of blood; acquisition of fresh urine and stool specimens; and, for children under the age of 10 , a rectal swab for bacteriological examinations. In addition, chest roentgenograms were routinely taken of persons who were six years or older.

\section{$\underline{\text { Results: }}$}

Estimated Fertility Rate per year, per 100 women aged 15-45, was 20.5. Birth Rate was 44.6. Infant Mortality Rate was 205 per 1000 live births.

Of the 1,317 blood smears made in the study, 8 were found positive for plasmodium malaria. All were identified as $P$. Vivax. Tuberculin tests revealed a positive reaction rate ranging from 36.2 to 59.3 percent for Tuberculin PPD-S, and from 38.7 to 53.3 for Tuberculin PPD-G. 
IV. OBJECTIVES OF THE CURRENT SURVEY (1990)

The objectives of this cross-border household survey were:

- To study the morbidity profile of the community;

- To investigate the available sources of health care, including maternal care, in the community and the level of their utilization;

- To gather data on the magnitude of expenditure on health care services;

- To study the mortality profile of the community;

- To get a sense of the extent of physical disability in the community and the relationship of such disability to the long civil war;

- To do a preliminary investigation on the status of child health and nutrition. 


\section{METHODOLOGY}

\section{Province Selection and Sample Size}

Provinces were selected according to the same rationale used to select provinces in previous household surveys, that is, by dividing Afghanistan into three main geographical areas: first, the central part including the mountainous area of Hindu Kush; second, the northern part including the Shoura Nazar area; and, third, the southern and western part.

Three provinces were selected one from each of the above categories: Wardak Province in the central part; Takhar Province in the northern part; and Kandahar Province in the southern part. (See Figure 1, Selected Provinces and Sample size by Household Survey.)

A total of 900 households were selected, $300 \mathrm{from}$ each province. This sample size allows results about morbidity and health care services in each province to stand alone statistically. Results for the rarer events of mortality and disability, however, may need to be combined among the three provinces. (See Table 1, Sample Size and Interviewers by Household Survey.)

This report describes the results of the survey in Wardak only. Kandahar and Takhar surveys are yet to be conducted.

\section{Field Supervisors and Interviewers}

Carrying out the proposed household survey in Afghanistan was complicated by the fact that the responsible organization, the Afghanistan Health Sector Support Project, was based in Peshawar, Pakistan and the survey was to be carried out in Afghanistan. To circumvent the resulting technical problems, the strategy for conducting household interviews was built around carefully selected field supervisors. Three Afghani physicians were chosen for these posts, trained in Peshawar, and then sent to the selected survey sites inside Afghanistan, where they led a team of interviewers.

Interviewers were selected after consideration of three basic options:

a. To recruit interviewers from refugee camps in and around Peshawar, train them in Peshawar and send them inside Afghanistan to carry out the interviews.

Analysis: This method would allow training of interviewers to take place in Peshawar under the close supervision of the project team and would therefore assure the quality of interviewer training. It would, however, be difficult to find qualified personnel in the refugee camps who would be willing to work inside Afghanistan for an extended period of time. Furthermore, since refugee camp personnel do not reside in the selected study sites they would be considered strangers to household members in the survey sample, a factor which might affect the interview. Also, logistically and for security reasons, it would be more difficult to arrange travel of a large number of interviewers from Peshawar into Afghanistan, than to use interviewers already in the country.

b. To recruit interviewers from each selected province.

Analysis: In this scenario, interviewers would be selected by field supervisors on site with assistance from local commanders. Although interviewers would be from the selected study site, i.e., not "strangers", this option puts a large burden on the field 
FIGURE 1

SELECTED PROVINCES AND SAMPLE SIZE BY HOUSEHOLD SURVEY

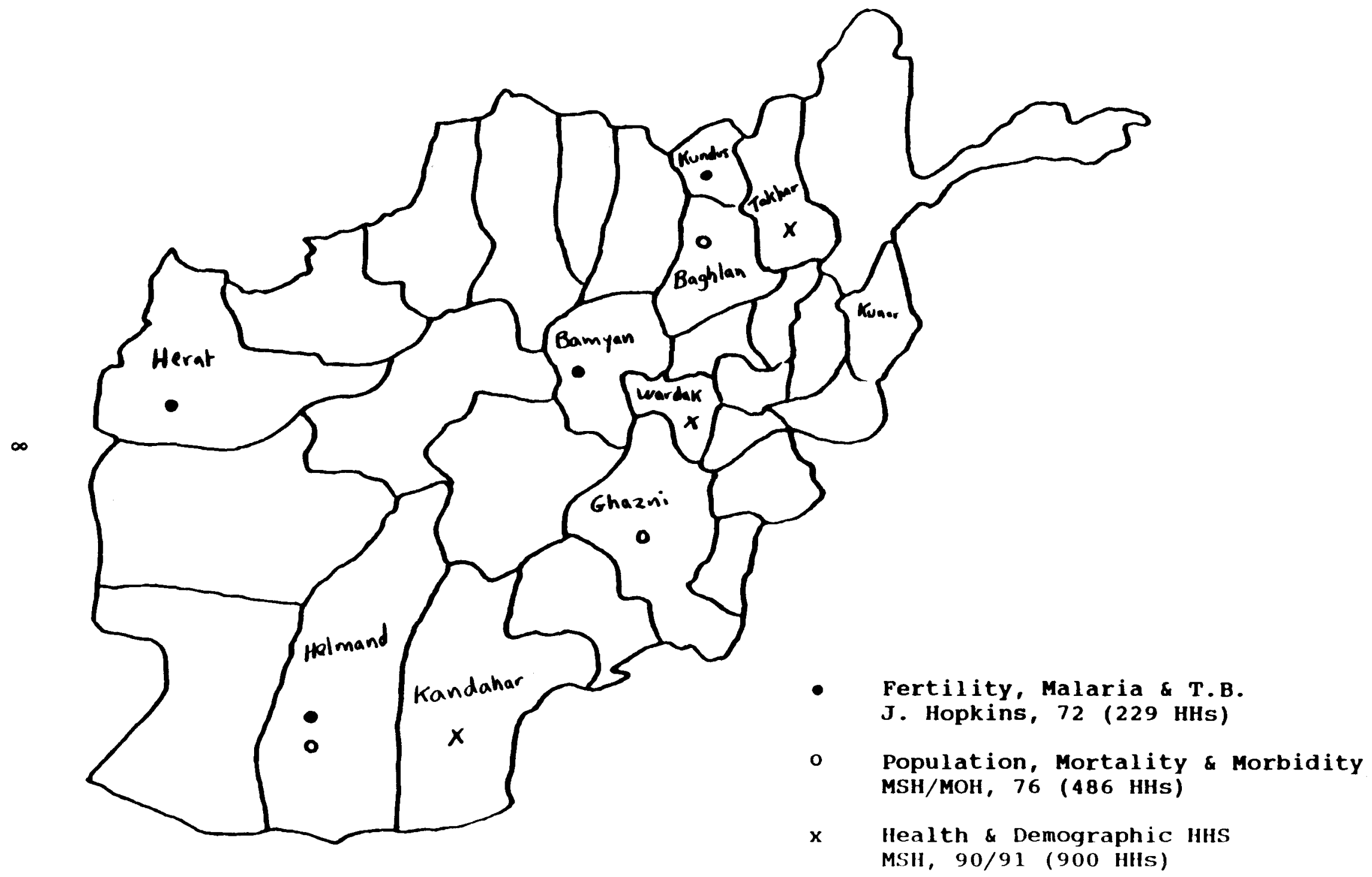


TABLE 1

SAMPLE SIZE AND INTERVIEWERS BY HOUSEHOLD SURVEY

\begin{tabular}{|c|c|c|c|}
\hline $\begin{array}{l}\text { Survey } \\
\text { Methodology }\end{array}$ & $\begin{array}{c}\text { Johns } \\
\text { Hopkins } \\
1972\end{array}$ & $\begin{array}{l}\text { MSH/ } \\
\text { MOH } \\
1976\end{array}$ & $\begin{array}{c}\text { MSH } \\
1990\end{array}$ \\
\hline -Selected provinces & $\begin{array}{c}\text { Kunduz } \\
\text { Bamyan } \\
\text { Helmand } \\
\text { Herat }\end{array}$ & $\begin{array}{l}\text { Baghlan } \\
\text { Ghazni } \\
\text { Helmand }\end{array}$ & $\begin{array}{c}\text { Takhar } \\
\text { Wardak } \\
\text { Kandahar }\end{array}$ \\
\hline -Number of villages & 4 & 17 & 27 \\
\hline -Number of HHs & 229 & 486 & 900 \\
\hline -Interviewer & $\begin{array}{l}\text { Male nurse } \\
\text { supported by } \\
\text { members of local } \\
\text { power structure }\end{array}$ & $\begin{array}{l}\text { One male and one } \\
\text { female interviewer }\end{array}$ & $\begin{array}{l}\text { Basic Health Worker } \\
\text { (Male) }\end{array}$ \\
\hline
\end{tabular}


supervisor to find, train and supervise a team of interviewers at the study site. Furthermore, the process of recruiting interviewers in the field, rather than being driven primarily by technical considerations, would be unduly subject to local political and tribal influences.

c. To use Basic Health Workers (BHWs) as survey interviewers.

Analysis: There are several advantages to using BHWs: they are already available in the community; they are known to household members in the villages they cover (and, hence, are not considered strangers); and, they are encouraged by their previous training and scope of work to learn about their community. The disadvantages of using BHWs include: (1) sample selection will be limited to those villages which have BHWs; and, (2) there is potential bias in responses to survey questions which relate to the BHW's role as a source of health care in the community.

The third option, using BHWs, was selected as the most suitable method of carrying out the field interviews given the security, logistical and technical aspects of the survey. The potential study bias imposed by using a male interviewer (BHW) who is an active part of the health system has been recognized and accounted for in setting study objectives and in questionnaire design.

\section{District, Village and Household Selection}

Within Wardak Province, districts with 10 or more BHWs - Chak Wardak, Sayed Abad and Jaghatoo - were selected. A total of 310 households were interviewed, 170 in Sayed Abad, 100 in Chak Wardak, and 40 in Jaghatoo. This distribution is in proportion to the estimated total population in the three districts." The sample was distributed over 10 villages. (See Table 2, Number of Households by District and Village.)

Within each district, at least 3 villages were randomly selected from a list of all villages with a BHW. In each village, a map was prepared by field supervisors and a census of all households in the village was prepared with assistance from senior local residents.

Once the total number of households to be interviewed in each district was known, the number of households to interview in each village was determined in proportion to the village population in relation to the total population in the 3 selected villages. If the village was not homogenous it was stratified into different geographic sections. From each stratified section the first household was selected randomly, and subsequent households were selected by taking every second, third, or fourth household based on the desired proportion of households to be interviewed in the village.

\section{Questionnaire}

The survey took place in September - October, 1990. The questionnaire consisted of the following forms:

General Form: includes information about household individuals, number of rooms, water, toilet facilities, annual income, and physical disability among household members.

\footnotetext{
"Source: Thomas H. Eighmy, Afghanistan Population Inside and Out, 1990.
} 
TABLE 2

NUMBER OF HOUSEHOLDS BY DISTRICT AND VILLAGE WARDAK PROVINCE

\begin{tabular}{|c|c|c|c|}
\hline Village & $\begin{array}{l}\text { Number of } \\
\text { Households in the } \\
\text { Sample }\end{array}$ & $\begin{array}{c}\text { Total Number of } \\
\text { Households in } \\
\text { Village }\end{array}$ & Percentage (\%) \\
\hline $\begin{array}{c}\text { Sayed A bad District: } \\
\text { Hassan Khel } \\
\text { Jamat Khel } \\
\text { Shedi Khel } \\
\text { Total: }\end{array}$ & $\begin{array}{r}42 \\
64 \\
64 \\
170\end{array}$ & $\begin{array}{l}135 \\
208 \\
208 \\
551\end{array}$ & $\begin{array}{l}31.1 \\
30.8 \\
30.8 \\
30.9\end{array}$ \\
\hline $\begin{array}{c}\text { Chak Wardak District: } \\
\text { Gardab } \\
\text { Hazar Bagh } \\
\text { Kaka Khel } \\
\text { Shahbaz Khan } \\
\text { Total: }\end{array}$ & $\begin{array}{r}24 \\
13 \\
30 \\
33 \\
100\end{array}$ & $\begin{array}{r}38 \\
21 \\
47 \\
52 \\
158\end{array}$ & $\begin{array}{l}63.2 \\
61.9 \\
63.8 \\
63.5 \\
63.3\end{array}$ \\
\hline $\begin{array}{l}\text { Jaghatoo District: } \\
\text { Akhtoom } \\
\text { Joshi } \\
\text { S Sareband } \\
\text { Total: }\end{array}$ & $\begin{array}{r}8 \\
6 \\
\frac{26}{40}\end{array}$ & $\begin{array}{r}30 \\
20 \\
91 \\
141\end{array}$ & $\begin{array}{l}26.7 \\
30.0 \\
28.6 \\
28.4\end{array}$ \\
\hline Total for the Province: & 310 & & \\
\hline
\end{tabular}


Morbidity Form: completed for every person in the household sick during the 2 weeks preceding the interview. Questions addressed symptoms, source of care and expenditure on health care.

Mortality Form: completed for every case of death in the household in the last 12 months.

Child's Form: for every child less than 5 years old in the sample. The form included questions about the child's feeding, weaning, vaccination, weight, height and arm circumference.

Woman's Form: for every woman that had a delivery during the last 12 months.

(A complete set of the questionnaire forms is included in Annex 1.)

\section{Special Challenges}

Conducting a survey inside Afghanistan in the middle of an active civil war while based in Pakistan was technically and logistically a very challenging task. Determining the age of individuals was particularly difficult. Special attention was given to verifying the age of individuals by linking the birth of the individual with a locally famous religious or political event (such as the death of a local Mullah). Field supervisors prepared a calendar of important local events known to the community.

Obtaining information about women while using male interviewers was another challenge. Recognizing the cultural reality of Afghanistan, the objectives of the survey were modified to minimize questions about women. The Woman's Form included only four (4) field-tested questions.

Getting local commanders' acceptance and support required a great deal of preparation beforehand. Preparation included mapping a travel route, determining the names of influential commanders along the way, and sending messages ahead to explain the reason for travel and the purpose of the survey. As a further safeguard, field supervisors linked their travel with an individual familiar with the route and known to the local commanders.

There was no guarantee of field supervisors' security along the way. They had to face the very real possibility of being robbed between Tank and Wana in Pakistan and along much of the route inside Afghanistan as well. Bad road conditions in Afghanistan added to the potential risk of travelling. In many areas along the way, field supervisors were stopped by Mujahedeen check points, and they actually experienced an attack by Kabul troops near the city of Ghazni.

Field supervisors also reported general difficulty in getting food, accommodation and transportation inside Afghanistan.

\section{Field Test}

During the week of August 29 - September 4, 1990, field testing of the household survey questionnaire and methodology took place in Khas Konar District, Konar Province. Interviews were completed for 54 households in 2 villages: Arazi Olia and Arazi Sufla.

\section{Lessons Learned:}

- Field supervisors were capable of travelling independently to Afghanistan, and of finding, training and working with BHW's. 
- Selected BHW's were capable of comprehending and carrying out household interviews when trained adequately and supervised closely.

- The test questionnaire was too long. More than 2 hours were needed to complete one household interview with the required level of accuracy. The questionnaire was revised and shortened accordingly.

- As expected, obtaining accurate information about age was difficult. A calendar of local events was tried, but not every respondent was aware of the local event mentioned by the interviewer.

- Field supervisors were initially unsure about the methodology for selecting houses. Written guidelines for house selection were developed to clarify the process after field testing revealed the field supervisors' confusion.

- Field supervisors needed to accompany the BWH in the field to decide on house selection and to answer questions.

Field supervisors needed to review forms and to give feedback to the BHW on a daily basis for completeness and accuracy. 


\section{RESULTS}

\section{Description of Population Sample}

A total of 310 household interviews were conducted. Eighty-three percent of respondents were males above the age of 20 . (Table 3 presents the distribution of respondents by age and sex.)

TABLE 3

DISTRIBUTION OF RESPONDENTS BY AGE \& SEX

\begin{tabular}{c|rc|rc|rr}
\hline \hline \multirow{2}{*}{$\begin{array}{c}\text { Respondent } \\
\text { Age }\end{array}$} & \multicolumn{2}{|c|}{ Females } & \multicolumn{2}{c|}{ Males } & \multicolumn{2}{c}{ Total } \\
\hline \hline <16 Years & 0 & 0 & 0 & 0 & 0 & 0 \\
16-20 Years & 1 & 11.1 & 8 & 88.9 & 9 & 100 \\
21-25 Years & 2 & 5.6 & 34 & 94.4 & 36 & 100 \\
26-30 Years & 7 & 18.0 & 32 & 88.0 & 39 & 100 \\
31-35 Years & 15 & 33.3 & 30 & 66.7 & 45 & 100 \\
$36-40$ Years & 10 & 25.6 & 29 & 74.4 & 39 & 100 \\
41-45 Years & 2 & 8.7 & 23 & 91.3 & 25 & 100 \\
46+ & 16 & 13.7 & 101 & 86.3 & 117 & 100 \\
\hline \hline TOTAL & 53 & 17.1 & 257 & 82.9 & 310 & 100 \\
\hline \hline
\end{tabular}

In $78 \%$ of households surveyed, the head of household was the source of information. In the remaining households, the wife responded $10 \%$ of the time and other family members/individuals the remaining $12 \%$ of the time.

The majority (96\%) of household heads were male, but 12 households were headed by women.

On average, there were 6 individuals (5.73) per household and the mode was 5 individuals. Children less than 5 years old were $22.6 \%$ of population, individuals less than 15 years old were $53.8 \%$ of total population, and women of childbearing age - 15 to 45 years - were $18 \%$. The sample included 942 males and 834 females with a sex ratio of 112.9 .

(Figure 2 shows the distribution of households by number of individuals. Figure 3 shows the age and sex distribution of the study population).

The majority of households $(68.1 \%)$ had one or more children under the age of $5,22.6 \%$ had one child, $30 \%$ had 2 children, $14.5 \%$ had 3 children, and $0.9 \%$ had more than 3 children.

The main sources for drinking water were "River" in 105 (33.9\%) households, "Well" in 78 (25.2\%) households, "Karez" in 74 (23.9\%) households and "Spring" in 78 (17.1\%) households. A Karez is a group of wells connected by an underground tunnel. 
FIGURE 2

Distribution of Households by

Number of individuals

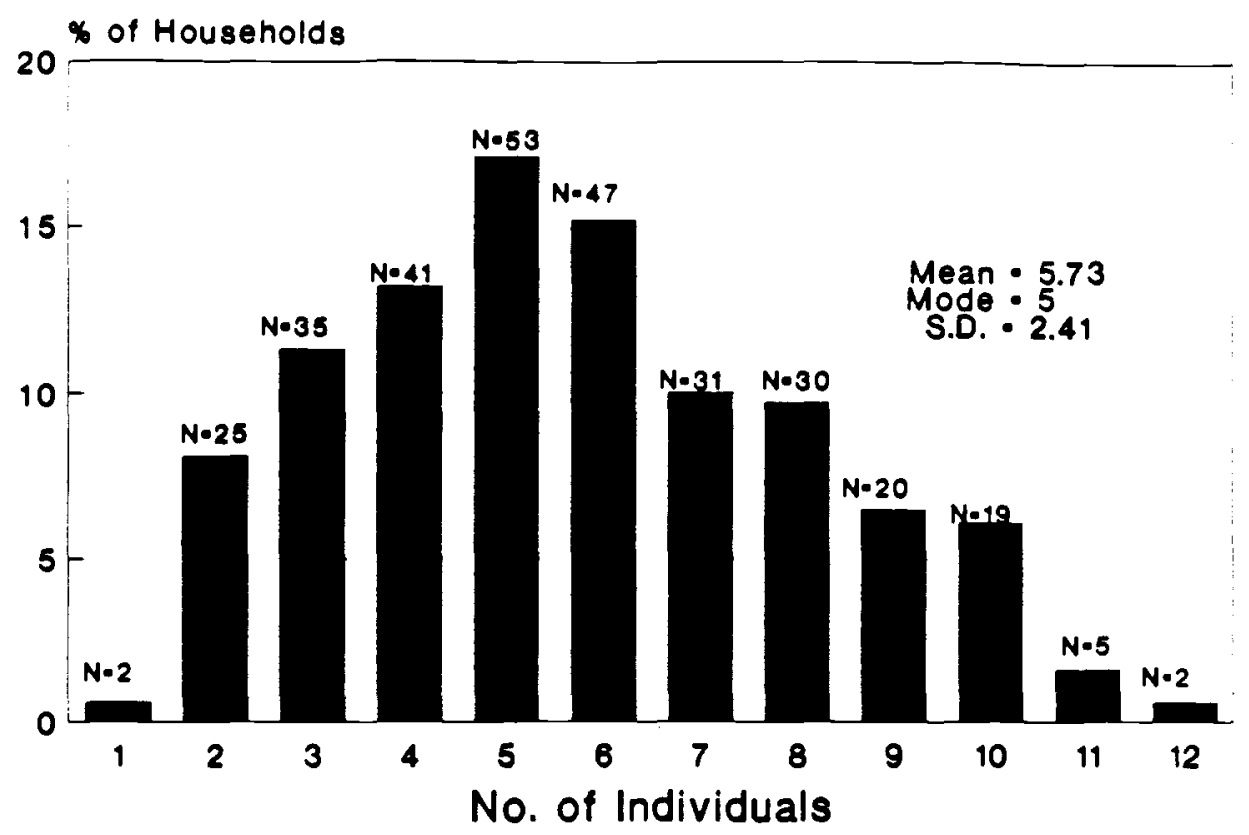

310 Households, 1776 Individuals

FIGURE 3

Age Sex Distribution for Individuals

Wardak Province, Afghanistan, 1990

Age in Years

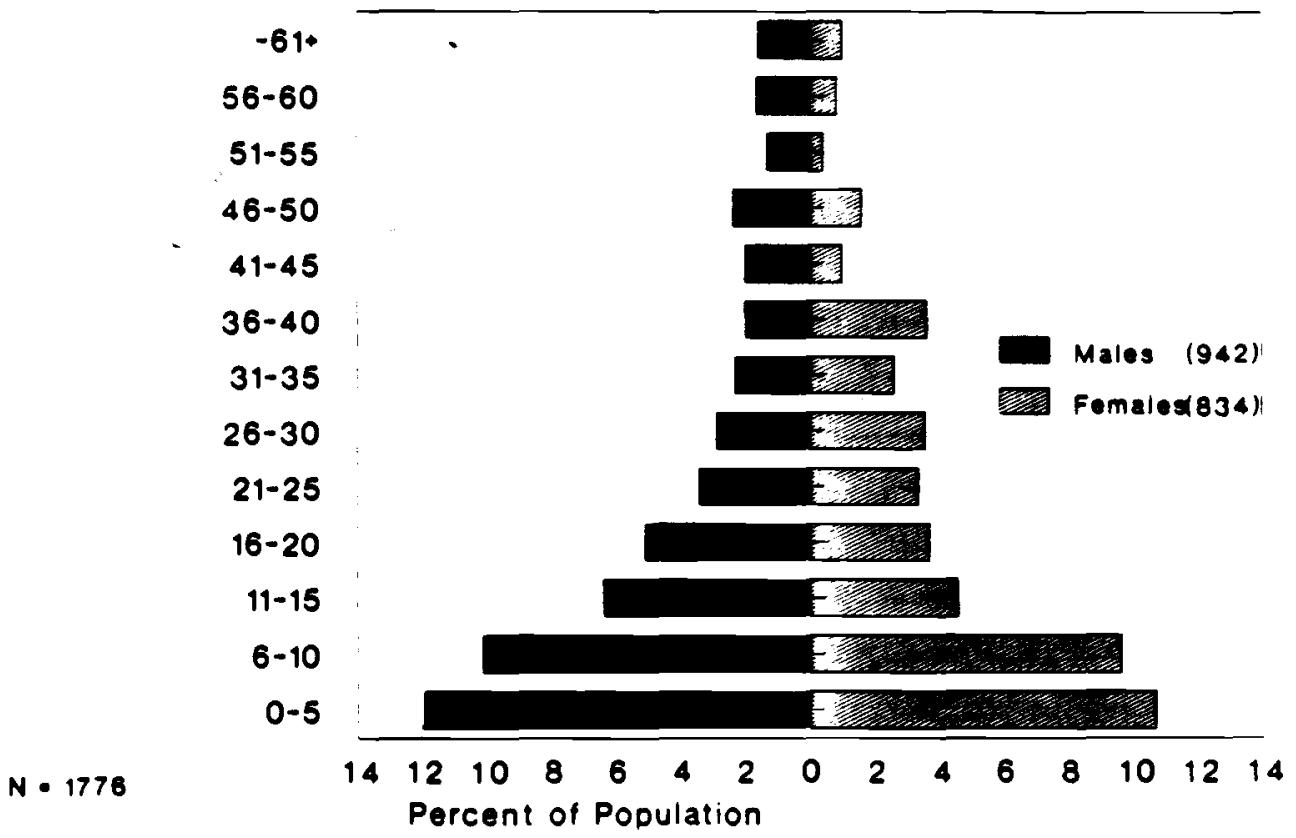


For toilet facilities, 286 houses (91.6\%) use "Kinarab", 19 houses (6.1\%) use an area outside the house, and 7 houses have a "Pit". A "Kinarab" consists of 2 small, double-story rooms built on the surface of the ground in one corner of the house. The two rooms are connected by a hole. The upper room is used as a toilet and the lower room is for storing sewage. Whenever the lower room is filled, sewage can be removed from another side opening and the "Kinarab" can be used again. On the other hand a "Pit" is a hole dug in the ground at one corner of the house. Whenever filled, a "Pit" is covered with mud and not used again.

There was no electricity in any of the sample houses.

The majority of households (82.5\%) were within $1 \mathrm{~km}$ from the nearest health facility, and $97.8 \%$ were within $2 \mathrm{~km}$. This relatively short distance can be attributed to the fact that the sample only included villages with BHW service. In Sayed Abad and Jaghatoo Districts there is one BHW for every 2,500 inhabitants, and in Chak Wardak District there is one BHW for every 5,000 inhabitants.

Forty-two percent of males and $1.6 \%$ of females above 5 years old could read and write. Table 4 displays the distribution of individuals over 5 years old who could read and write, by age group and sex.

TABLE 4

ABILITY TO READ \& WRITE BY AGE \& SEX FOR POPULATION ABOVE 5 YEARS OLD

\begin{tabular}{|c|c|c|c|c|c|c|}
\hline Age Group & $\begin{array}{l}\text { No. Who } \\
\text { Can Read } \\
\text { \& Write }\end{array}$ & $\begin{array}{l}\text { FEMALE } \\
\text { Sample } \\
\text { Population }\end{array}$ & $\%$ & $\begin{array}{l}\text { No. Who } \\
\text { Can Read } \\
\text { \& Write }\end{array}$ & $\begin{array}{l}\text { MALES } \\
\text { Sample } \\
\text { Population }\end{array}$ & $\%$ \\
\hline $\begin{array}{l}6-10 \text { years } \\
11-15 \\
16-45 \\
46+ \\
\end{array}$ & $\begin{array}{l}0 \\
3 \\
7 \\
0\end{array}$ & $\begin{array}{r}171 \\
88 \\
314 \\
70 \\
\end{array}$ & $\begin{array}{l}0 \\
3.4 \\
2.2 \\
0 \\
\end{array}$ & $\begin{array}{r}58 \\
74 \\
141 \\
32 \\
\end{array}$ & $\begin{array}{l}180 \\
114 \\
314 \\
122 \\
\end{array}$ & $\begin{array}{l}32.2 \\
64.9 \\
44.9 \\
26.2\end{array}$ \\
\hline TOTAL & 10 & 643 & 1.6 & 305 & 730 & 41.8 \\
\hline
\end{tabular}


Very few females in the sample (1\%) had attended schools, while $45 \%$ of males had one or more years of school. (See Table 5).

TABLE 5

YEARS IN SCHOOL BY AGE GROUP \& SEX FOR OVER 5 YEAR OLD POPULATION

\begin{tabular}{|c|c|c|c|c|c|c|c|c|c|c|c|c|}
\hline $\begin{array}{l}\text { Age } \\
\text { Group }\end{array}$ & $\begin{array}{l}\text { No. } \\
0\end{array}$ & $\begin{array}{l}\text { Indi } \\
1-3\end{array}$ & $\begin{array}{l}\text { FEM } \\
\text { iduals } \\
4-6\end{array}$ & $\begin{array}{r}\text { LES } \\
\text { with } \\
7-9\end{array}$ & $\begin{array}{r}\text { School } \\
10+\end{array}$ & $\begin{array}{l}\text { Yr }= \\
\text { Total }\end{array}$ & $0^{1}$ & $\underset{1-3}{\text { of In }}$ & $\begin{array}{r}M A \\
4-6\end{array}$ & $\begin{array}{l}\text { ES } \\
\text { with } \\
7-9\end{array}$ & $\begin{array}{r}\text { School } \\
10+\end{array}$ & $r=$ \\
\hline $\begin{array}{l}6-10 \text { Years } \\
11-15 \\
16-45 \\
46+\end{array}$ & $\begin{array}{r}171 \\
85 \\
309 \\
70\end{array}$ & $\begin{array}{l}0 \\
0 \\
0 \\
0\end{array}$ & $\begin{array}{l}0 \\
3 \\
3 \\
0\end{array}$ & $\begin{array}{l}0 \\
0 \\
1 \\
0\end{array}$ & $\begin{array}{l}0 \\
0 \\
0 \\
0\end{array}$ & $\begin{array}{r}171 \\
88 \\
315 \\
70\end{array}$ & $\begin{array}{r}100 \\
34 \\
170 \\
91\end{array}$ & $\begin{array}{r}73 \\
32 \\
17 \\
0\end{array}$ & $\begin{array}{r}7 \\
41 \\
28 \\
10\end{array}$ & $\begin{array}{r}0 \\
6 \\
40 \\
8\end{array}$ & $\begin{array}{r}0 \\
1 \\
55 \\
5\end{array}$ & $\begin{array}{l}180 \\
114 \\
310 \\
114\end{array}$ \\
\hline TOTAL & $\begin{array}{l}635 \\
98.9\end{array}$ & $\begin{array}{l}0 \\
0\end{array}$ & $\begin{array}{l}6 \\
0.9\end{array}$ & $\begin{array}{l}1 \\
0\end{array}$ & $\begin{array}{l}0 \\
0\end{array}$ & $\begin{array}{r}642 \\
100 \%\end{array}$ & $\begin{array}{l}395 \\
55.0\end{array}$ & $\begin{array}{l}112 \\
15.6\end{array}$ & $\begin{array}{l}86 \\
12.0\end{array}$ & $\begin{array}{c}54 \\
7.5\end{array}$ & $\begin{array}{l}61 \\
8.5\end{array}$ & $\begin{array}{l}718 \\
100 \%\end{array}$ \\
\hline
\end{tabular}

Studying the occupational status of the sample population revealed that all females in the sample were reported to have no work outside the house. For males, almost one third of the population over 5 years old were also without work, $26.6 \%$ worked in farming, and $23.8 \%$ were students. (See Table 6).

2. Morbidity Pattern, Source of Consultation and Expenditure on Health Services

\subsection{Morbidity Pattern}

Respondents were asked whether any individual in the household had been sick in the last 2 weeks. A detailed investigation of the symptoms of the sickness was done by interviewers using the survey questionnaire.

During September - October, 1990, 231 individuals were reported to have been sick within the previous 2 week period. The distribution of sick persons in the sample is shown in Figure 4. Comparing Figure 4 to Figure 5, "Population Sample by Age Group", one can conclude that, in general, the different age groups in the sample population are not equally represented in the morbidity pie. Females 16 to 45 years were significantly more represented in the morbidity pie than in the population sample pie $(P<0.01)$. This finding points out the importance of this age group from the health care point of view, especially in Afghanistan where most health workers, are males. This finding also gives confidence in the study results since it was expected that females health problems would be under-represented in the study because the interviewers were all males.

Infectious diseases were on the top of the morbidity list for all age groups. Acute Respiratory Infection counted for $19.1 \%$ of all cases, acute diarrhea and dysentery counted for $20.3 \%$. Dysentery accounted for as much as $11.2 \%$ of all cases. As feared, suspected T.B. cases were high, $8.7 \%$. Suspected malaria cases were $5.6 \%$ of all cases. Table 7 shows the distribution of probable diagnosis by age group.

The decision on diagnosis was not made by interviewers, it was made at the data analysis stage by combining a group of symptoms to form a probable diagnosis. (See Diagnosis Scheme in Figure 6). 
TABLE 6

OCCUPATION BY AGE GROUP

FOR MALES OVER 5 YEARS OLD

\begin{tabular}{l|rrrr|rc}
\hline & \multicolumn{5}{c|}{ Age Group in Years } & \\
\multicolumn{1}{c|}{ Occupation } & $6-10$ & $11-15$ & $16-45$ & $46+$ & TOTAL & $\%$ \\
\hline \hline None & 104 & 21 & 85 & 32 & 242 & 33.7 \\
Farming & 4 & 17 & 114 & 56 & 191 & 26.6 \\
Student & 69 & 72 & 30 & 0 & 171 & 23.8 \\
Driver & 0 & 0 & 16 & 6 & 22 & 3.1 \\
Mullah & 0 & 0 & 8 & 13 & 21 & 2.9 \\
Clerk/ & 0 & 0 & 10 & 6 & 16 & 2.2 \\
Office Worker & 0 & 0 & 9 & 2 & 11 & 1.5 \\
Carpenter & 0 & 0 & 10 & 1 & 11 & 1.5 \\
Teacher & 0 & 3 & 26 & 4 & 33 & 4.6 \\
* Other & 177 & 113 & 308 & 120 & 718 & 100 \\
\hline \hline TOTAL & & & & & & \\
\hline
\end{tabular}

*Other categories included one Doctor, 3 Nurses and 4 Basic Health Workers. 


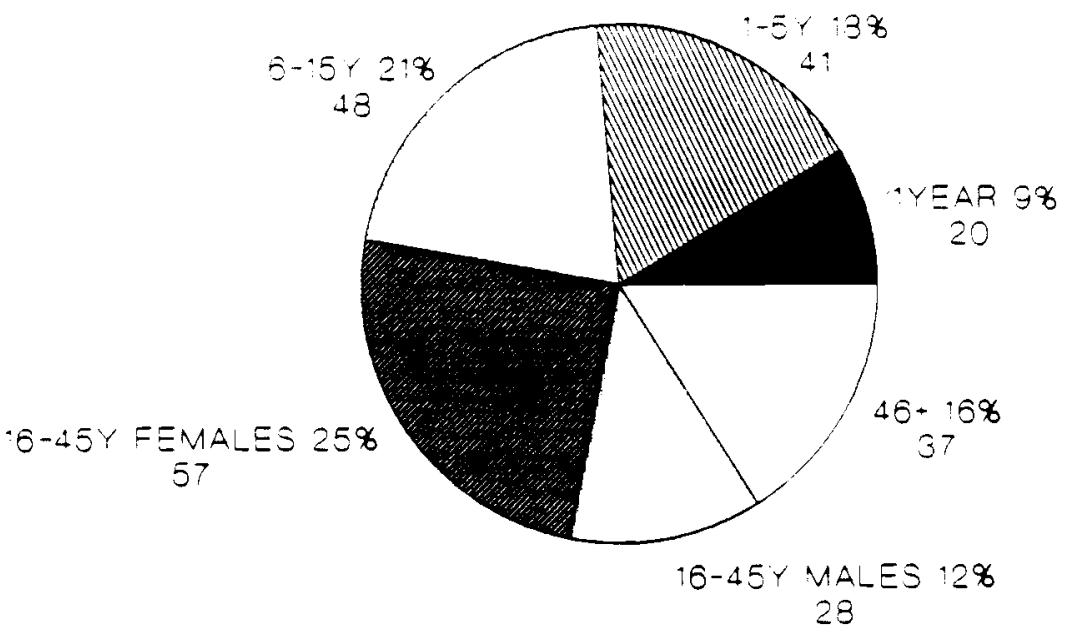

$N \cdot 231$

FIGURE 5

\section{POPULATION SAMPLE BY AGE GROUP}

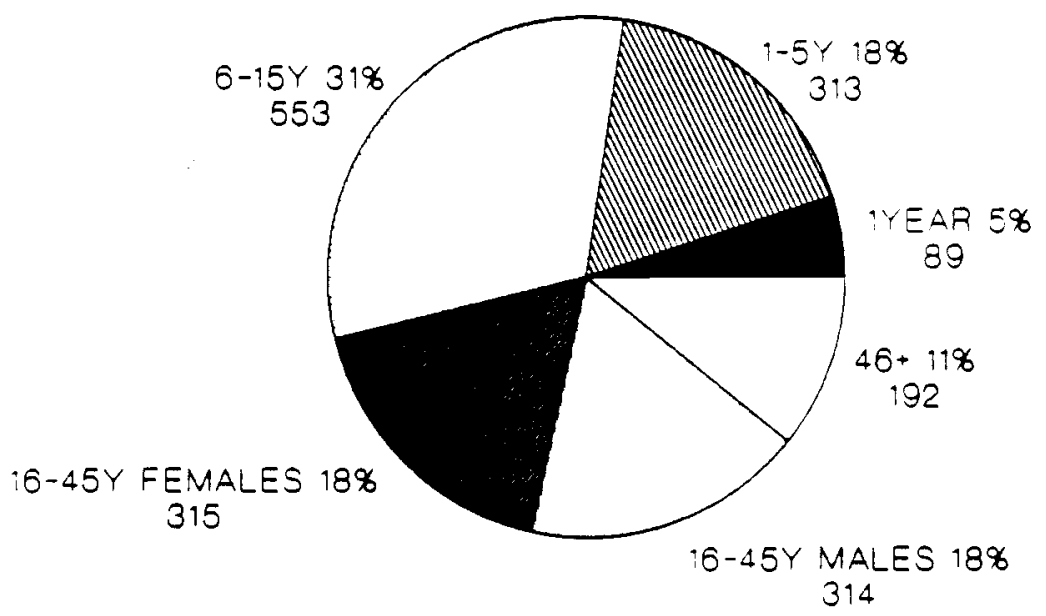

$N \cdot 1776$ 
TABLE 7

PROBABLE DIAGNOSIS BY AGE GROUP

\begin{tabular}{|c|c|c|c|c|}
\hline Probable Diagnosis & $\begin{array}{c}\text { Less than } \\
5 \text { Years }\end{array}$ & 6 Years + & $\begin{array}{l}\text { All Age } \\
\text { Groups }\end{array}$ & $\%$ of Total \\
\hline Acute Respiratory Inf. & 12 & 34 & 46 & $19.1 \%$ \\
\hline Fever & 11 & 21 & 31 & $12.9 \%$ \\
\hline Dysentery & 13 & 14 & 27 & $11.2 \%$ \\
\hline Sore Throat & 1 & 22 & 23 & $9.5 \%$ \\
\hline Diarrhea & 18 & 4 & 22 & $9.1 \%$ \\
\hline Suspected T.B. & 0 & 21 & 21 & $8.7 \%$ \\
\hline Fever \& Colic & 0 & 15 & 15 & $6.2 \%$ \\
\hline Suspected Malaria & 0 & 14 & 14 & $5.8 \%$ \\
\hline Otitis Media & 5 & 3 & 8 & $3.3 \%$ \\
\hline Eye Infection & 1 & 6 & 7 & $2.9 \%$ \\
\hline Skin Infection & 1 & 5 & 6 & $2.5 \%$ \\
\hline Vomiting Alone & 0 & 6 & 6 & $2.5 \%$ \\
\hline Cardio Vascular Dis. & 0 & 4 & 4 & $1.7 \%$ \\
\hline Worms & 3 & 1 & 4 & $1.7 \%$ \\
\hline Gynecological Dis. & 0 & 3 & 3 & $1.2 \%$ \\
\hline Suspected Measles & 1 & 1 & 2 & $0.8 \%$ \\
\hline Other & 0 & 2 & 2 & $0.8 \%$ \\
\hline TOTAL & 66 & 176 & 241 & $100.0 \%$ \\
\hline
\end{tabular}




\title{
Diagnosis Scheme
}

\author{
- ARI - Cough + Fever for ' 2 months \\ - Dysentery - Blood or Mucous in Stools \\ - Diarrhea - 4+ Motions Per Day \\ - T.B. - Cough with Sputum for > 2 months \\ Coughing Blood or Red Sputum \\ - Malaria - Fever + Chills + Headache \\ - Fever - Fever with no other symptoms
}

\subsection{Source of Consultation}

For each identif ied morbidity case, the source of consultation, if any, was identified. While 28 ( $12.1 \%)$ sick individuals did not seek any health care for their sickness, on average each case sought 1.57 consultations from different sources. The sources of care which were most frequently called upon were: Hospital or Clinic; Basic Health Worker; Private doctor; Dokan for Medicine; Mullah; and Pharmacy. A dokan for medicine is a shop owned by a non-health professional and it carries medicine along with other items. (See Figure 7, Source of Consultation for Sickness.)

Hospitals and clinics were the most frequently used source of care, which may reflect the relatively high concentration of clinics in Wardak Province compared to other Provinces.

The BHW was shown to be an important source of health consultation in the community. More than $45 \%$ of patients consulted with their BHW. This finding could be due to the fact that the survey sample was taken from all villages with a BHW service.

The level of satisfaction with the selected source of consultation was investigated. Table 8 presents the study findings. 
FIGURE 7

\section{Source of Consultation for Sickness \\ Wardak Province, Afghanistan, 1990}

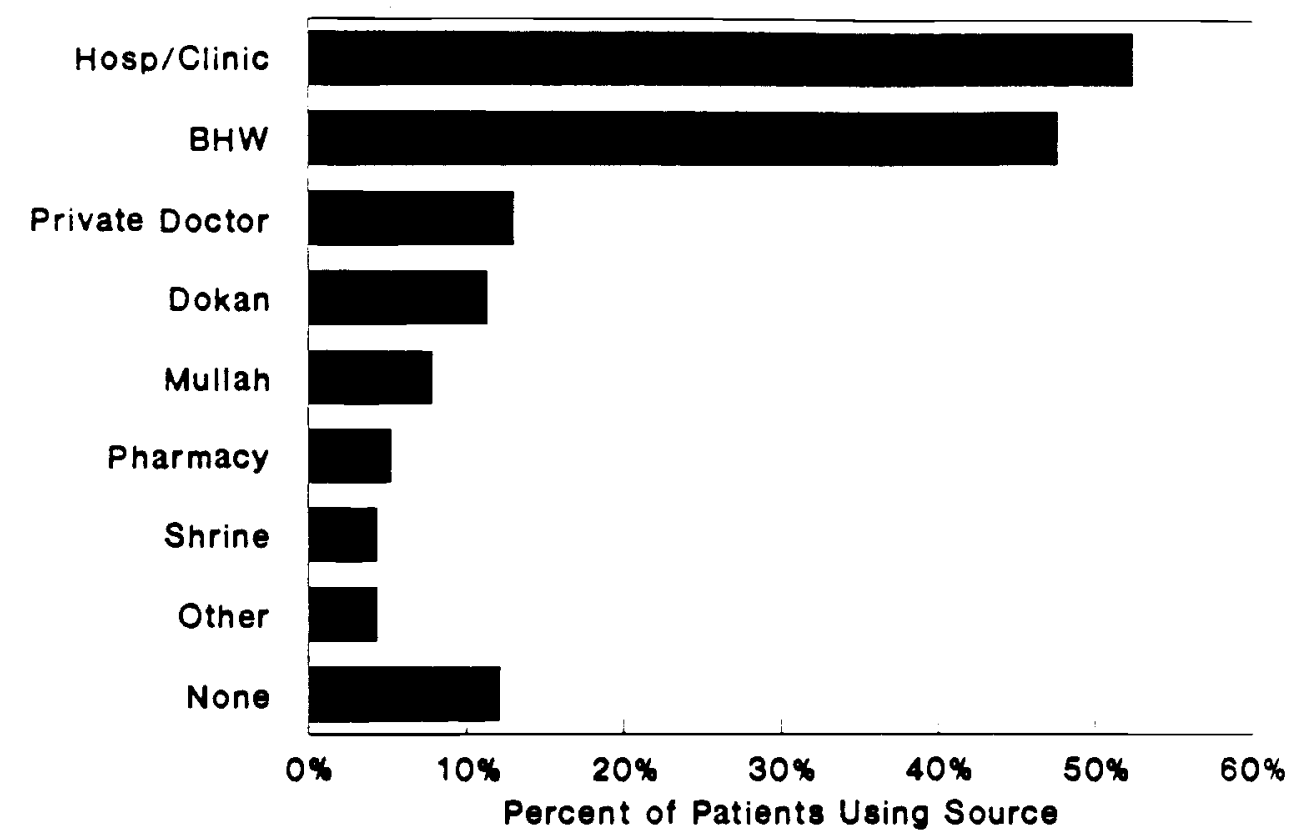

$N \cdot 231$ patients, 365 consultations

TABLE 8

PATIENT SATISFACTION BY SOURCE OF CONSULTATION

\begin{tabular}{l|cc|cc|cc}
\hline \multirow{2}{*}{$\begin{array}{l}\text { Source of } \\
\text { Consultation }\end{array}$} & \multicolumn{2}{|c|}{ Satisfied } & \multicolumn{2}{c|}{ Not Satisfied } & \multicolumn{2}{c}{ Total } \\
\hline No. & $\%$ & No. & $\%$ & No. & $\%$ \\
\hline $\begin{array}{l}\text { Hospital/Clinic } \\
\text { Worker }\end{array}$ & 62 & 50.8 & 60 & 49.2 & 122 & 100 \\
Private Doctor & 83 & 74.8 & 28 & 25.2 & 111 & 100 \\
$\begin{array}{l}\text { Dokan for } \\
\text { Medicine }\end{array}$ & 13 & 44.8 & 16 & 55.2 & 29 & 100 \\
Mullah & 9 & 61.5 & 10 & 38.5 & 26 & 100 \\
Pharmacy & 7 & 50.0 & 9 & 50.0 & 18 & 100 \\
Shrine & 5 & 50.0 & 5 & 50.0 & 10 & 100 \\
\hline
\end{tabular}




\subsection{Expenditure on Health Services}

Patients who decided to seek consultation were asked whether they had paid in cash or in kind for the health services they received. Expenses in kind were translated to money value by interviewers. Information about transportation expenses, consultation expenses, and medicine expenses was collected.

Private doctors and pharmacies were the most expensive sources. The average cost of service from each of these two sources were more than 4,000 Afghanis per patient ( $1 \$ U S=550$ Afghanis as of October, 1990). The least expensive source of care was the BHW who, according to study results, provided his services for free.

On average, for all sources of health care, each patient paid 1,324 Afghanis in cash or in kind for health services. Most of this amount (66\%) was for drugs, $27 \%$ for transportation, and the rest $(7 \%)$ for consultation fee.

(Figure 8).

Looking at the average expense on health services can be misleading since not all patients actually paid for services. While no patients paid for BHW's services, and only one fifth of patients paid for hospital or clinic services, almost all patients paid one expense or another when receiving services from a pharmacy, a dokan for medicine, or a private doctor (Figure 9). If the average expenditure is calculated only for patients who actually paid for health services, that is by excluding patients who received health care for free, figures will be much higher reflecting the actual financial burden that a patient had to bear when paying for health services (Figure 10). Figure 10 reveals that for the one fif th of patients who pay for hospital or clinic services, the average cost is over 8,000 Afghanis. The price of drugs consume the largest share of the cost followed by transportation expenses and consultation fees.

In order to understand the magnitude of the financial burden that patients bore for receiving health care, it was necessary to compare what patients paid to the average household income. Interviewers collected information about the annual household income from all sources for all 310 households in the sample. Results showed a great variation in household income from less than 50,000 Afs. to more than 400,000 Afs. per year (Figure 11).

The average annual income per household was 226,246 Afs., or \$US 411.4. Figure 12 shows the average annual income per household distributed by the sources of income. The important sources of income were: wages in cash (35\% of the average annual income), farm product sales (30\%), and remittances from relatives who work outside the country (24\%). Farm products sales were the most frequently mentioned source of income, ( $70.3 \%$ of households), followed by wages in cash ( $58.6 \%$ of households). (See Figure 13). Comparing Figure 12 with Figure 13 reveals that receiving remittance from relatives working outside the country is an important source of income for only a small fraction of households. While remittances formed $24 \%$ of the average annual income pie (Figure 12), only $10 \%$ of households received any remittances (Figure 13).

The financial burden a household had to bear to seek health care for a sick person is presented in Figure 14. On average, a household had to pay more than one-and-a-half days' worth of income for health services to the sick individual. If the burden is calculated only for patients who actually paid for health service -- that is, excluding those who received free service -- on average, a household had to pay 6.5 days' worth of income. 
FIGURE 8

\section{Average Expenditure by}

Source of Care

5 Thousands of Afghanis

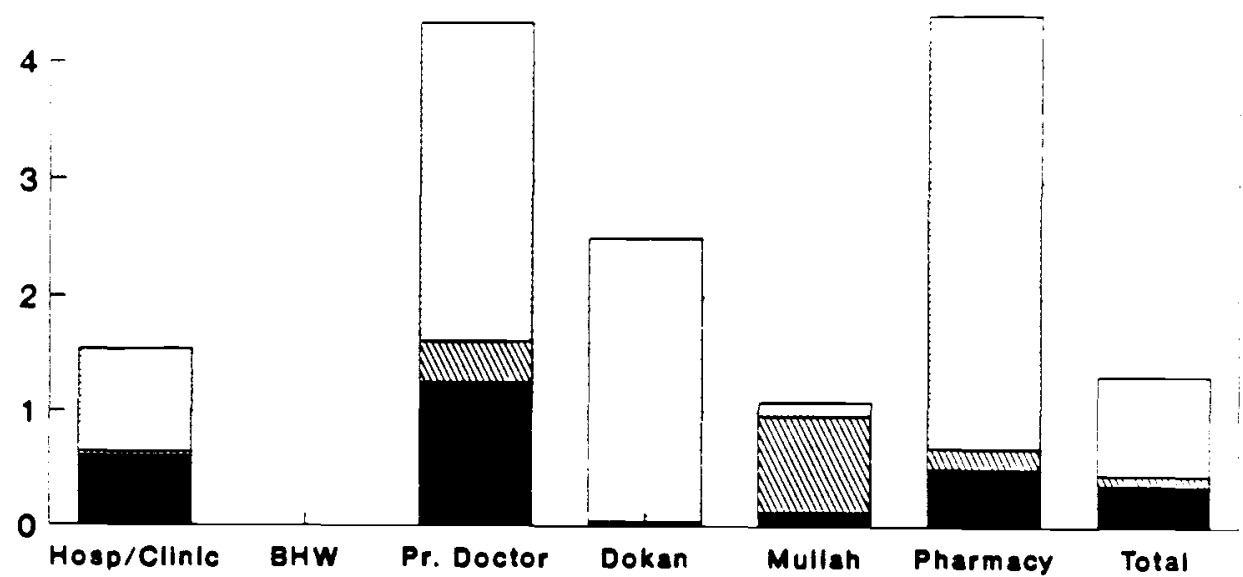

Transport Consultation $\square$ Drugs

1 \$ US. 550 Afganis

FIGURE 9

Proportion of Patients Who Paid for Care by Source of Care

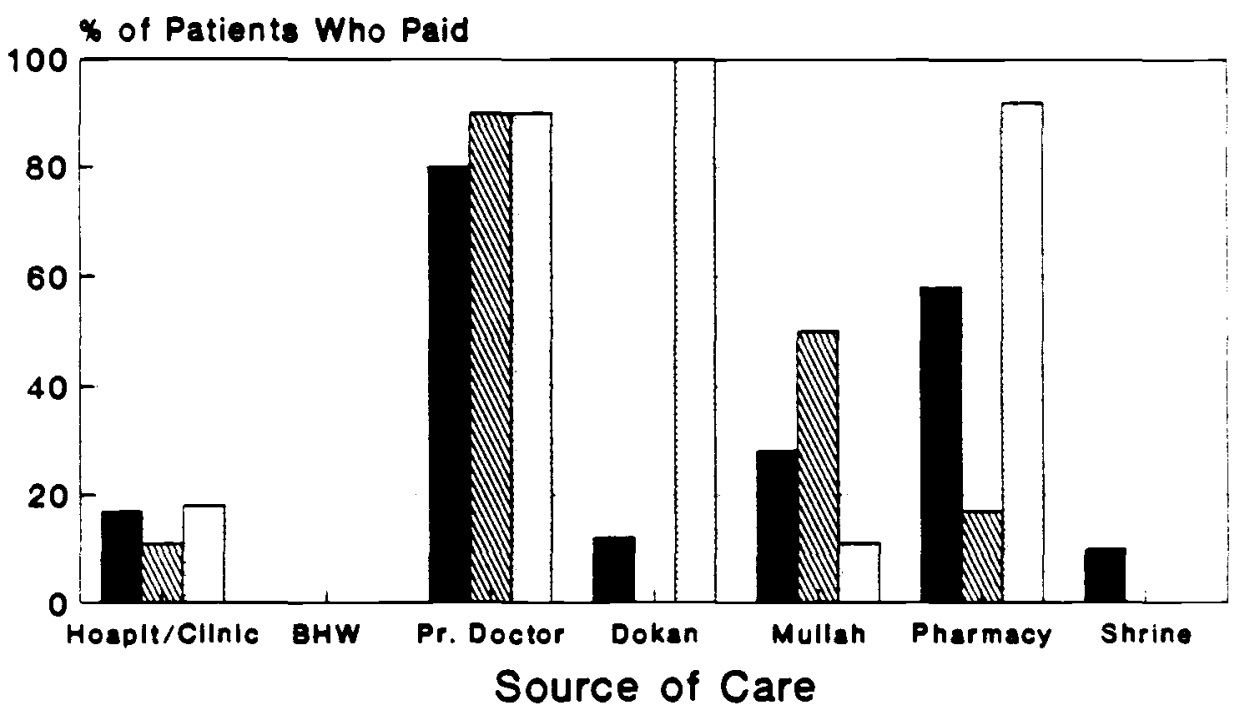


Average Expenditure by source of Care for Patients Who Paid

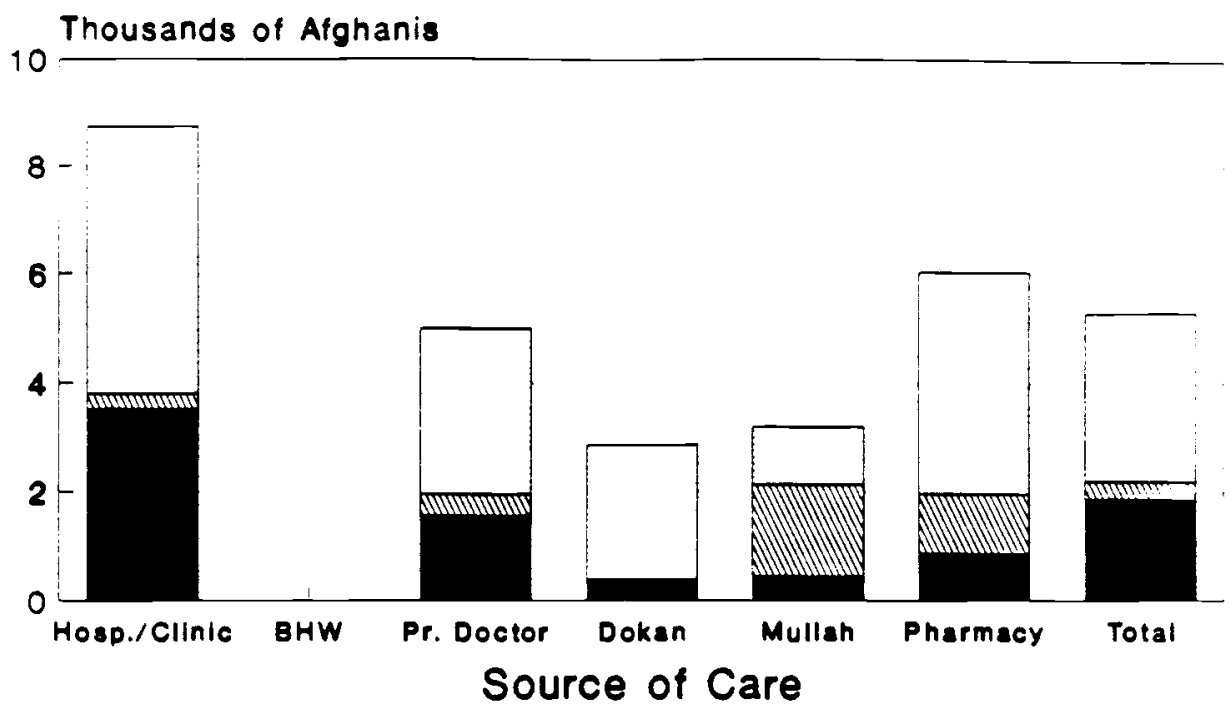

Transport $\$$ Mlut Consultation $\square$ Drugs

1 S US - 550 Afghanis

FIGURE 11

Total Annual Income per Household

Wardak Province, Afghanistan, 1990

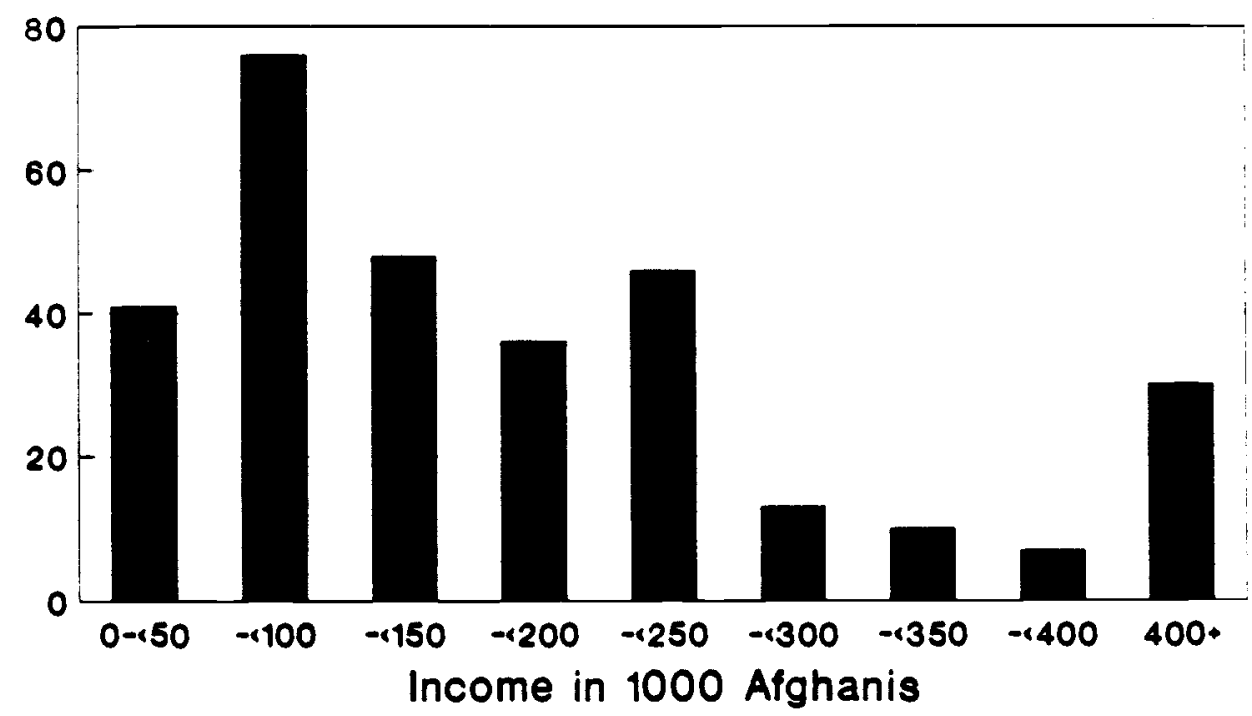

No. of Households

Average - 226,246 Af, 1SUS - 550Af 


\section{Average Annual Income Per Household}

Wardak Province, Afghanistan, 1990

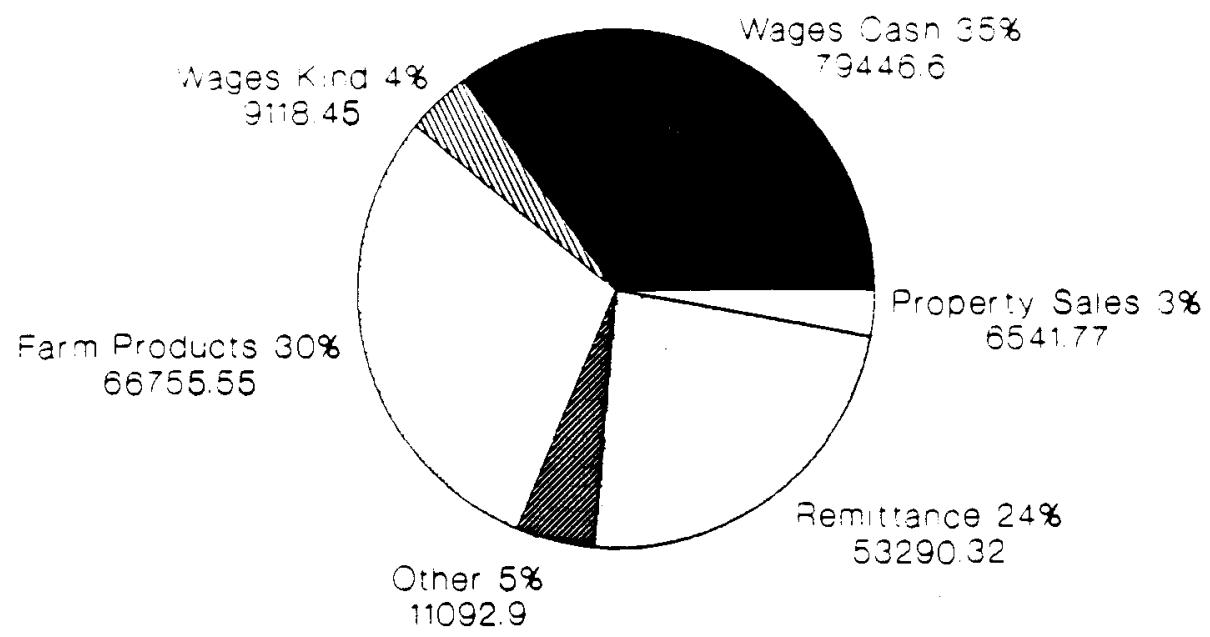

Income is in Afghanis, 1Sus - 550 Af

Total Average Annual Income $=226,246$ Af

FIGURE 13

Source of Income per Household

Wardak Province, Afghanistan, 1990

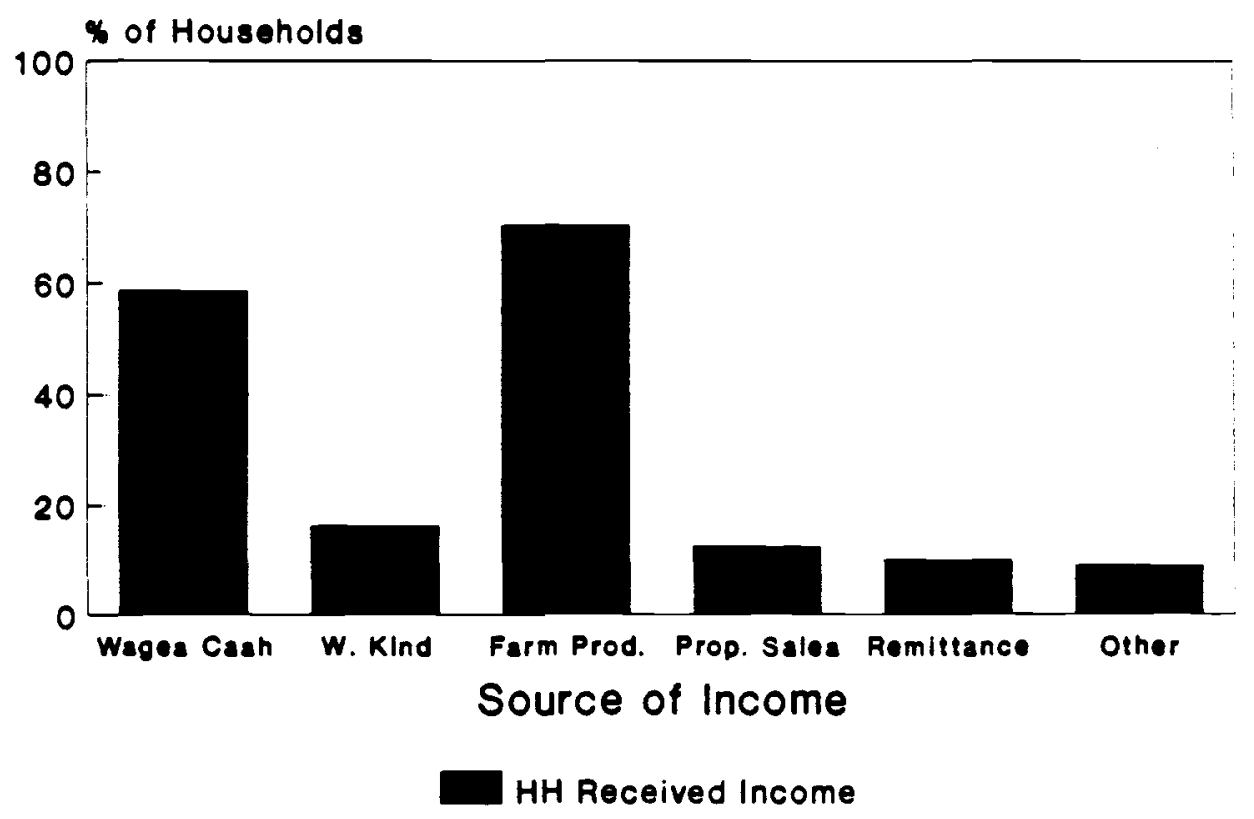




\section{Average Expenditure on Sickness in Relation to Average Household Income.}

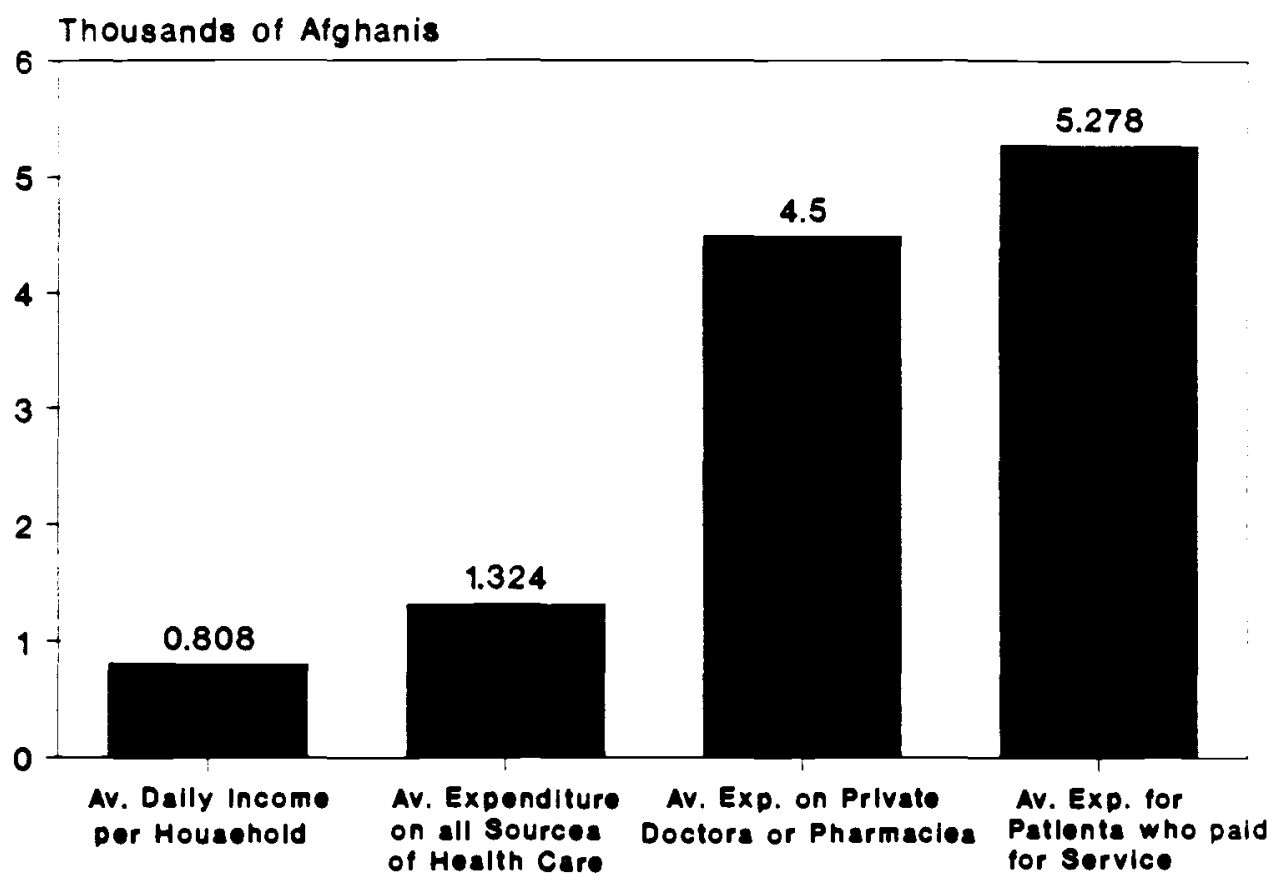

\section{Physical Disability}

Because of the long civil war in Afghanistan the survey addressed, to a limited extent, the question of physical disability. The extent of disability in the community, the causes of disability, and type of disability were investigated. Out of 1,776 individuals in the study sample, 25 were physically disabled (1.4\%). While this figure seems low in relation to the length and the magnitude of the civil war, it is hard to conclude whether the extend of disability is high or low without comparing this figure with figures from a population with no civil war or with figures from other communities which have suffered from a prolonged civil war.

Causes of disability were mainly war accidents (32\%), injury (24\%), and musculoskeletal disorder (16\%). (See Figure 15.)

Cases identified as "musculoskeletal" disorders were not based on clinical diagnosis but rather on the respondent's understanding of the nature of the disease that resulted in the physical disability. For that reason, Poliomyelitis cases, although caused by a nervous system infection, could well be included under that category.

The areas of physical disability are presented in Figure 16. 
FIGURE 15

Causes of Disability

Wardak Province, Afghanistan, 1990

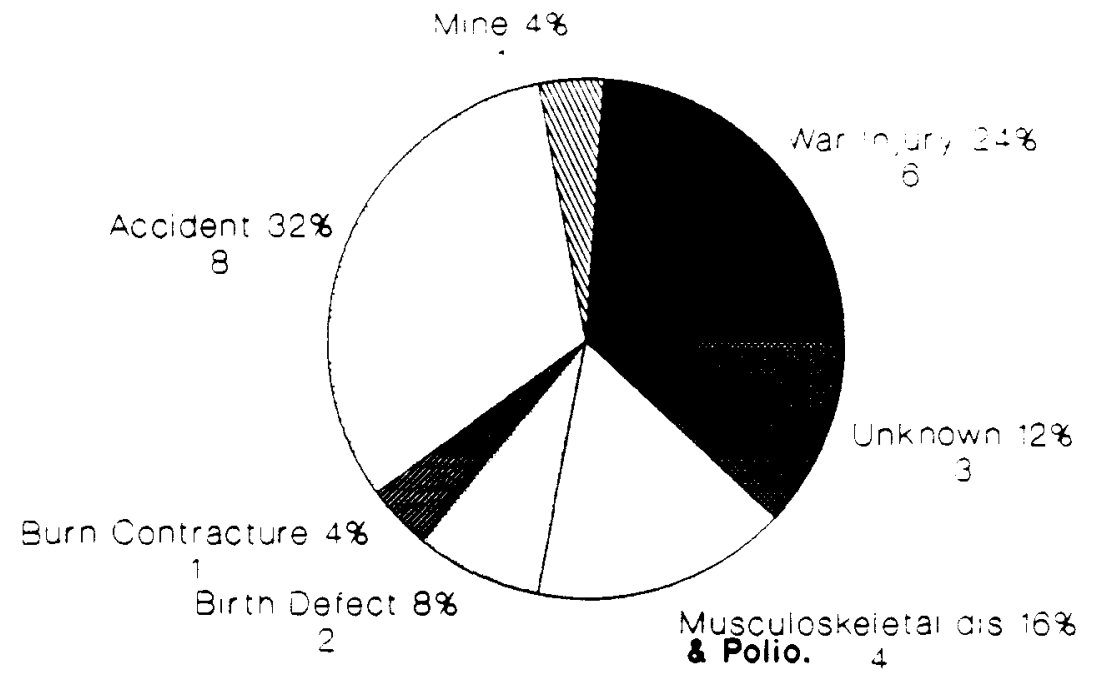

$N \cdot 25$

FIGURE 16

Type of Disability

Wardak Province, Afghanistan, 1990

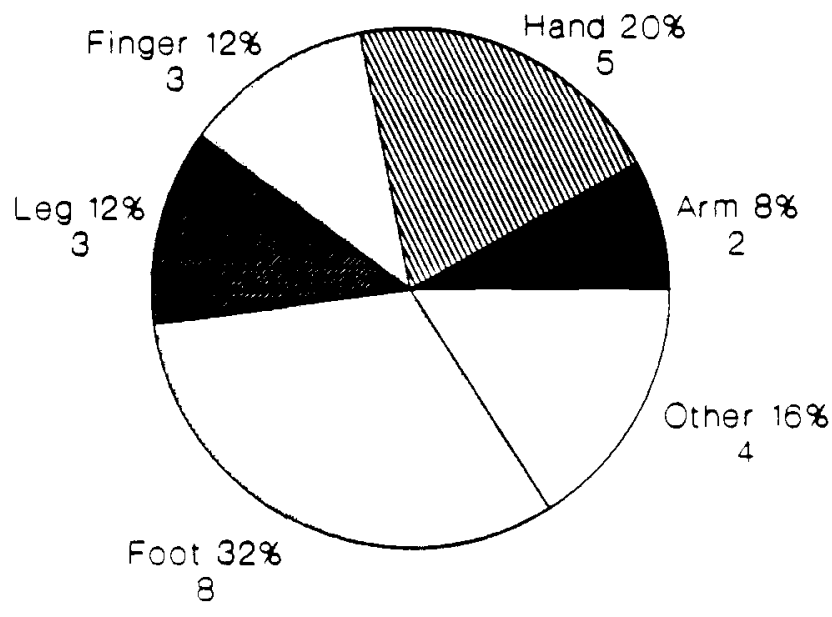

$N \cdot 25$ 


\section{Sources of Prenatal and Natal Care}

Collecting specific information about woman's health was a contraversial issue. While planners for maternal and child health in Afghanistan are in need of such information, the Afghan culture would not permit a male interviewer to ask questions about woman's health. The field testing in Konar Province was particularly useful in giving reserchers an idea about what topics, within the area of woman's health can be investigated by a male interviewer.

As a result of the field testing many questions about the pregnancy history of women were eliminated. The woman's consequently was limited to 4 field tested questions about sources of prenatal and natal care.

Women who had given birth during the 12 months prior to the interview were identified. Information about the outcome of delivery, the source of prenatal care and natal care, if any, was collected.

Table 9 shows the distribution of deliveries by the age of women. Although none of the women were below 16 years old, $17.6 \%$ of women were in the high risk group of under 20 years old.

There was only one reported stillbirth out of the 85 deliveries.

TABLE 9

\section{DELIVERIES IN 12 MONTHS BY AGE OF WOMEN}

\begin{tabular}{l|cc}
\hline Age of Woman & $\begin{array}{l}\text { No. of } \\
\text { Deliveries }\end{array}$ & $\%$ \\
\hline 15 years or less & 0 & 0 \\
$16-20$ & 15 & 17.6 \\
$21-25$ & 20 & 23.5 \\
$26-30$ & 27 & 31.8 \\
$31-35$ & 11 & 12.9 \\
$36-40$ & 10 & 11.8 \\
$41+$ & 2 & 2.4 \\
\hline \hline TOTAL & 85 & 100.0 \\
\hline
\end{tabular}

Thirty women out of $82(36.6 \%)$ who answered the question about whether they had received medical care for their pregnancy, responded positively. The important sources of care during pregnancy were dais, mullahs, and private doctors. A Dai is a women who lives in the village, usually elder, and has experience in delivering babies. (Traditional birth attendent). (Figure 17).

Fifteen women (18.3\%) claimed that they have received a vaccination during their pregnancy.

More than $90 \%$ of deliveries took place at home. The Dai, the mother in law and the mother were the main sources of help during delivery. (Figure 18). 


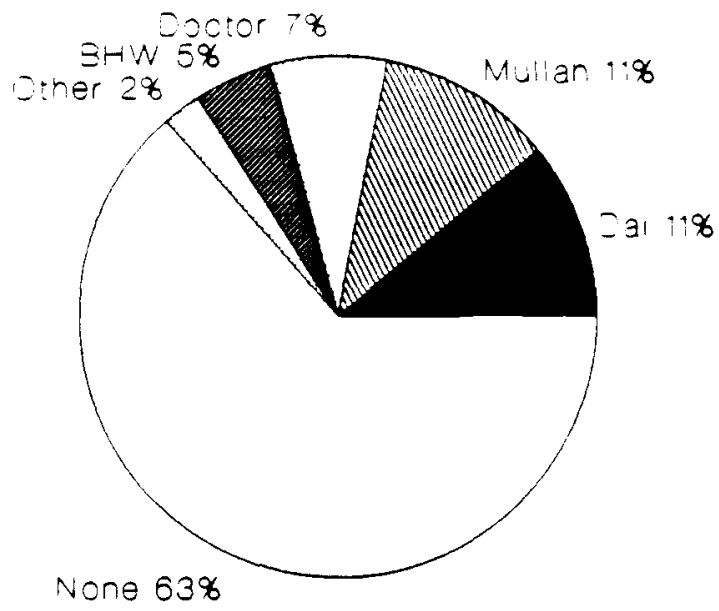

$N \cdot 82$

FIGURE 18

Who Helped in the Delivery

Wardak Province, Afghanistan, 1990

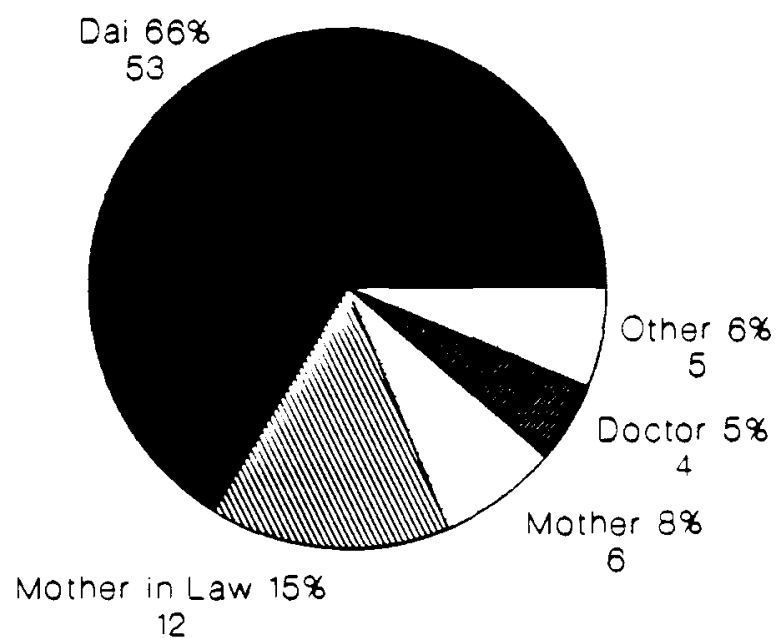

$N \cdot 80$ 


\section{Child Feeding and Vaccination}

All children under 5 years old in the sample were identified and the feeding history of each was investigated. Children's weight, height and arm circumference were measured. Both arms were examined for T.B. scar. The following is a summary of the important results about child's feeding and vaccination. Results about children's growth measurement have not yet been analyzed.

All 392 children in the sample were breast fed for a period of time in their life. Sixty percent of children did not have any other foods or fluids, apart from milk, introduced in their meals by the age of 6 months. (Table 10). This late introduction of supplementary nutrition might be one main cause of malnutrition among children. It also reflects a general lack of understanding from the community about proper weaning practice which suggests the introduction of supplementary feeding at the age of 4 months.

Almost two thirds of children had received one or more vaccination. There was no significant difference between males and females vaccination status. (Table 11). A T.B. scar was detected in $56 \%$ of children, and, once again, there was no significant difference between males and females. (Table 12).

\section{Mortality}

Mortality within the 12 months prior to the interview was investigated through a verbal autopsy technique. In spite of the under reporting of mortality in general, and in particular for infants under 3 months old, children under 5 years comprised more than half the deaths. Out of the nineteen mortality cases detected, 10 were under 5 years old (53\%), and 4 were under one $(21 \%)$.

Infectious diseases were the major cause of death. Diarrhea and acute respiratory infection caused almost half the deaths.

(Figure 19).

FIGURE 19

\section{Cause of Death \\ Wardak Province, Afghanistan, 1990}

$N \cdot 21$ Causes, 19 Deaths

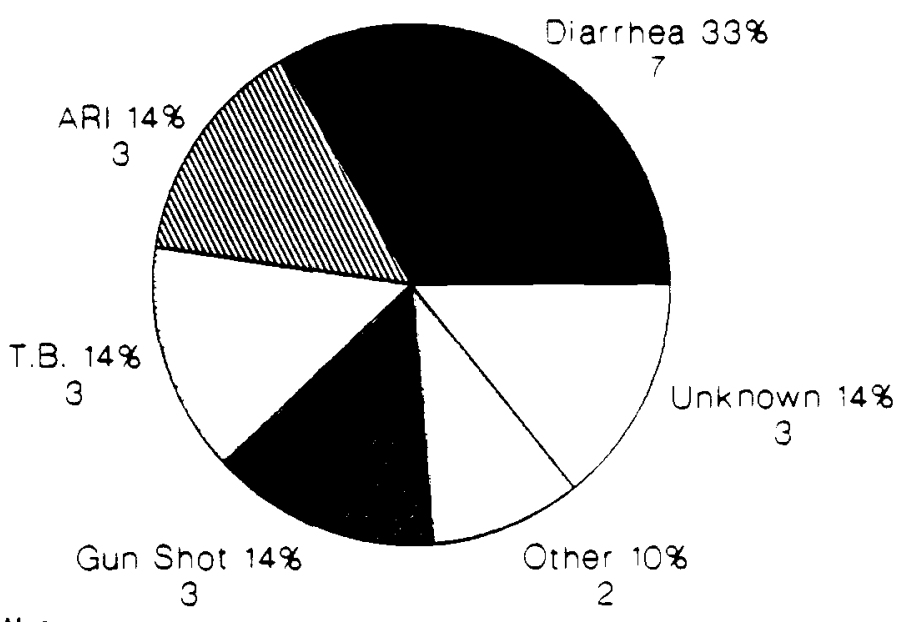


TABLE 10

AGE WHEN FOOD OR FLUIDS

WERE INTRODUCED FOR THE FIRST TIME

\begin{tabular}{c|ccc}
\hline $\begin{array}{l}\text { Age in } \\
\text { Months }\end{array}$ & $\begin{array}{l}\text { Number } \\
\text { of } \\
\text { Children }\end{array}$ & Percent & $\begin{array}{l}\text { Cumulative } \\
\text { Percent }\end{array}$ \\
\hline \hline 1 & 1 & 0.3 & 0.3 \\
2 & 2 & 0.6 & 0.9 \\
3 & 4 & 1.2 & 2.0 \\
4 & 18 & 5.3 & 7.3 \\
5 & 30 & 8.8 & 16.1 \\
6 & 82 & 24.0 & 40.1 \\
7 & 48 & 14.0 & 54.1 \\
8 & 53 & 15.5 & 69.6 \\
9 & 27 & 7.9 & 77.5 \\
10 & 16 & 4.7 & 82.2 \\
11 & 5 & 1.5 & 83.6 \\
12 & 41 & 12.0 & 95.6 \\
$13+$ & 15 & 4.4 & 100.0 \\
\hline \hline TOTAL & 342 & 100.0 & \\
\hline
\end{tabular}


TABLE 11

DISTRIBUTION OF CHILDREN UNDER 5 YEARS OLD WHO HAVE EVER BEEN VACCINATED

BY SEX

\begin{tabular}{|c|c|c|c|c|c|c|}
\hline \multirow{3}{*}{$\begin{array}{l}\text { Ever } \\
\text { Vaccinated? }\end{array}$} & \multicolumn{4}{|c|}{ Sex } & \multicolumn{2}{|c|}{ Total } \\
\hline & \multicolumn{2}{|c|}{ Male } & \multicolumn{2}{|c|}{ Female } & \multirow[b]{2}{*}{ No. } & \multirow[b]{2}{*}{$\%$} \\
\hline & No. & $\%$ & No. & $\%$ & & \\
\hline Yes & 125 & 60.4 & 113 & 61.1 & 238 & 60.7 \\
\hline No & 82 & 39.6 & 72 & 38.9 & 154 & 39.3 \\
\hline Total & 207 & 100.0 & 185 & 100.0 & 392 & 100.0 \\
\hline
\end{tabular}

TABLE 12

PRESENCE OF T.B. SCAR

AMONG CHILDREN UNDER 5 YEARS OLD

BY SEX

\begin{tabular}{|c|c|c|c|c|c|c|}
\hline \multirow{3}{*}{$\begin{array}{l}\text { Scar } \\
\text { Present }\end{array}$} & \multicolumn{4}{|c|}{ Sex } & \multicolumn{2}{|c|}{ Total } \\
\hline & \multicolumn{2}{|c|}{ Male } & \multicolumn{2}{|c|}{ Female } & \multirow[b]{2}{*}{ No. } & \multirow[b]{2}{*}{$\%$} \\
\hline & No. & $\%$ & No. & $\%$ & & \\
\hline Yes & 115 & 56.1 & 102 & 56.4 & 217 & 56.2 \\
\hline No & 90 & 43.9 & 79 & 43.6 & 169 & 43.8 \\
\hline Total & 205 & 100.0 & 181 & 100.0 & 386 & 100.0 \\
\hline
\end{tabular}


ANNEX I: Questionnaire Forms 


\section{Demographic and Health Household Survev}

- Province:

- District:

- Town/Village:

- Household Number:

- Name of Respondent: Sex:
- Name of Interviewer:

- Interviewer Code:

- Name of Field Supervisor:

- Interview Date:

- Relation to Head:

\begin{tabular}{|c|c|c|c|c|c|c|c|c|c|}
\hline \multirow{2}{*}{$\begin{array}{l}\text { ID } \\
\text { No. }\end{array}$} & \multirow[b]{2}{*}{ Name } & \multirow{2}{*}{$\begin{array}{c}\text { Relationahip to Head } \\
\text { of Household }\end{array}$} & \multirow[b]{2}{*}{ Sex } & \multicolumn{2}{|c|}{ Age } & \multirow{2}{*}{$\begin{array}{l}\text { Marital } \\
\text { Status }\end{array}$} & \multirow{2}{*}{$\begin{array}{l}\text { Years in } \\
\text { School }\end{array}$} & \multirow{2}{*}{$\begin{array}{l}\text { Reads \& } \\
\text { Writes }\end{array}$} & \multirow[b]{2}{*}{ Occupation } \\
\hline & & & & Years & Months & & & & \\
\hline \multicolumn{10}{|l|}{01} \\
\hline \multicolumn{10}{|l|}{02} \\
\hline \multicolumn{10}{|l|}{03} \\
\hline \multicolumn{10}{|l|}{04} \\
\hline \multicolumn{10}{|l|}{05} \\
\hline \multicolumn{10}{|l|}{06} \\
\hline \multicolumn{10}{|l|}{07} \\
\hline \multicolumn{10}{|l|}{08} \\
\hline \multicolumn{10}{|l|}{09} \\
\hline \multicolumn{10}{|l|}{10} \\
\hline \multicolumn{10}{|l|}{11} \\
\hline \multicolumn{10}{|l|}{12} \\
\hline \multicolumn{10}{|l|}{13} \\
\hline \multicolumn{10}{|l|}{14} \\
\hline 15 & & & & & & & & & \\
\hline
\end{tabular}

- Total number of children under 5 years old:

- Total number of live births in the household over the past 12 months:

- During the lant 2 weeks, has anybody in the household been sick?

Yee___________ If yes, how many?

- God forbid, during the last 12 monthe has anybody in the household died?

Yes__________ If yes, how many"?

"make sure neonates are included

- No. of women who delivered during the last 12 months: 
1. How many people live in this house? Persons

2. How many rooms do you have in this house? Rooms

3. What is the source of water your household uses for drinking?

Pipe in house ___ Pipe in yard Public tap Well River Spring_Rain

Other

4. How long does it take to go to the source of water, get water, and come back?

"Use your judgement to validate the answer.

5. What kind of toilet facility does your household have?

Latrine_Pit___Special place inside house__Special place outside house_Other

6. Does your household have electricity?

Yes___________ yes:

-What source? Private generator_Public source____Other

7. Do you have: -Radio?

Yes___No

-TV?

Yes____No

8. How far is the neareat health facility? Km.

9.

"Observe \& Record

-Main noor material:

Earth_Cement_Wood__Tiles Other:

$-W$ alls:

Mud__Brick_Wood__Hay___Other:
Mud__Brick__ Wood_Hay___Other:

- Roof:

-Economic status of household:

Very poor Poor Average_Good Very good 
- Is there anybody in the household with a physical disability? Yes

Yes

\begin{tabular}{|c|c|c|c|c|c|}
\hline $\begin{array}{l}\text { ID } \\
\text { No. }\end{array}$ & $\begin{array}{c}\text { Disability Description } \\
\text { Missing: }\end{array}$ & $\begin{array}{l}\text { Can hel } \\
\text { she work? }\end{array}$ & $\begin{array}{l}\text { Can hef } \\
\text { she go to } \\
\text { toilet } \\
\text { alone? }\end{array}$ & Cause & $\begin{array}{c}\text { Source of Care for } \\
\text { Disability }\end{array}$ \\
\hline 01 & eye, arm, hand, finger, leg, foot, other: & $\begin{array}{l}\text { yes } \\
\text { no }\end{array}$ & $\begin{array}{l}\text { yes } \\
\text { no }\end{array}$ & mine, war, injury, accident, other: & \\
\hline 02 & eye, arm, hand, finger, leg, foot, other: & $\begin{array}{l}\text { yes } \\
\text { no }\end{array}$ & $\begin{array}{l}\text { yes } \\
\text { no }\end{array}$ & mine, war, injury, accident, other: & \\
\hline 03 & eye, orm, hand, finger, leg, foot, other: & $\begin{array}{l}\text { yes } \\
\text { no }\end{array}$ & $\begin{array}{l}\text { yes } \\
\text { no }\end{array}$ & mine, war, injury, accident, other: & \\
\hline 04 & eye, arm, hand, finger, leg, foot, other: & $\begin{array}{l}\text { yes } \\
\text { no }\end{array}$ & $\begin{array}{l}\text { yes } \\
\text { no }\end{array}$ & mine, war, injury, accident, other: & \\
\hline 05 & eye, arm, hand, finger, leg, foot, other: & $\begin{array}{l}\text { yes } \\
\text { no }\end{array}$ & $\begin{array}{l}\text { yes } \\
\text { no }\end{array}$ & mine, war, injury, accident, other: & \\
\hline
\end{tabular}

-Kindly provide information on all kinds of income to this household during the last 12 months:

- Wages cash:

- Hages kind:

- Money value of farm product:

-From business:

-From handicraft products at home:

-Remittances from other relatives:

-Sales of property:

- Other sources (gift, Zakat): 
One Form for Every Sick Person in the Last Two (2) Weeks

Province: District: Town/Village:

Household No: Name of Head of Household:

1. Name of sick person:

3. Age in years/months:

5. Did "name" have:

-Fever?

-Fever and chills?

-Diarrhea?
Yes No Yes___ No Yes___No

-Mucous in atool?

-Blood in stool?

-Worma in atool?

-No. of motiona/day:

2. Identification No.:

4. Sex:

If yea, for how many days?

If yes, for how many days?

If yes, for how many days?

Yes____No

Yes No No

Yes___No_____

"for under 5 years

\section{-Vomiting? \\ -Colic? \\ -Convulsione? \\ -Cough?}

-Difficulty in breathing?

-Sore throat?

-Ear discharge?

-Eye infection?

-Skin rash?

-Joint pain?

-Headache?

-Other

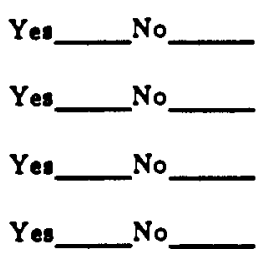

If yes, for how long?

-Dry or with sputum?

-If with sputum, what is the colour of sputum?

-Did "name" cough blood? Yee___No

Yes___No

Ye ___ No

Yee____No

Yen____No

Yes___No

Yes___No No___

Yes___No 
-Mine injury

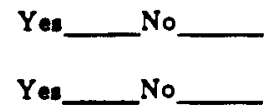

-War injury

$$
\text { ar? }
$$

-Accident not related to war?

-Was "name" hospitalized? Yes____No No _________

6. Did you are anybody in your family seek consultation for "name'a" illneas?

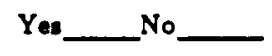

If yes, from whom?

How much did it cost in cash/kind?

\begin{tabular}{|c|c|c|c|c|c|c|c|c|c|}
\hline \multirow{2}{*}{$\begin{array}{l}\text { Source of } \\
\text { Consultation }\end{array}$} & \multirow{2}{*}{$\begin{array}{l}\text { Visited } \\
\text { (V) }\end{array}$} & \multirow{2}{*}{$\begin{array}{l}\text { Trane- } \\
\text { port } \\
\text { Cost }\end{array}$} & \multirow{2}{*}{$\begin{array}{l}\text { Consultation } \\
\text { Cost }\end{array}$} & \multirow[b]{2}{*}{$\begin{array}{l}\text { Drus } \\
\text { Coat }\end{array}$} & \multirow[b]{2}{*}{$\begin{array}{l}\text { Total } \\
\text { Coat }\end{array}$} & \multicolumn{4}{|c|}{$\begin{array}{l}\text { How satinfied are you with } \\
\text { your coneultant? }\end{array}$} \\
\hline & & & & & & $\begin{array}{l}\text { very } \\
\text { eatilis- } \\
\text { fied }\end{array}$ & $\begin{array}{l}\text { satis- } \\
\text { fied }\end{array}$ & $\begin{array}{l}\text { un- } \\
\text { satis- } \\
\text { fied }\end{array}$ & $\begin{array}{l}\text { very } \\
\text { unsatis- } \\
\text { fied }\end{array}$ \\
\hline \multicolumn{10}{|l|}{ Hakimji } \\
\hline \multicolumn{10}{|l|}{ Shekasta Band } \\
\hline \multicolumn{10}{|l|}{ Barber } \\
\hline \multicolumn{10}{|l|}{ Mullah } \\
\hline \multicolumn{10}{|l|}{ Pharmacy } \\
\hline \multicolumn{10}{|c|}{ Dokan for Medicine } \\
\hline \multicolumn{10}{|l|}{ Private Doctor } \\
\hline \multicolumn{10}{|l|}{ B.H.W. } \\
\hline \multicolumn{10}{|l|}{ Compounder } \\
\hline \multicolumn{10}{|l|}{ Shrine } \\
\hline \multicolumn{10}{|l|}{ Honpital/Clinic } \\
\hline Other: & & & & & & & & & \\
\hline
\end{tabular}

7. Did "name" receive any modication?

$$
\text { If yes, what? }
$$

*Aek to see the modicine and try to identify.

8. 
One Form for Every Death in the Household During Last Twelve (12) Months

Province: District: Town/Village:

Household No: Name of Head of Household:

1. Name of person who died:

2. Identification No.:

3. Age in years/months:

4. Sex:

5. For how long was "name" ill before he/she died?

5. One week prior to death did "name" have:

-Fever?

Yes

No

- Fever and chille?

Yes

-Diarrhea?

Yes__ No

-Mucous in stool?

-Blood in atool?

-No. of motions/day*:

"for under 5 years
-Vomiting?

-Colic?

-Convulsions?

-Cough?

-Did "name" lose weight?

-Difficulty in breathing?

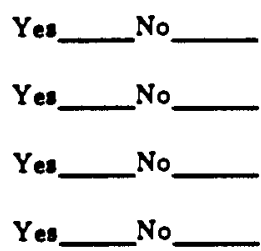

Yes___No

Yes___No

Yes____No

Was death due to:

-Mine injury?

$$
\text { Yes____No }
$$

- War injury?

Yes____No

-Injury not related to war "accident"?

Yes___No

-Pregnancy related?

Yes___No

-Other cause(s):
If yes, for how many days?

If yes, for how many days?

If yes, for how many days?

Yes___No

Yes____No N__ . 
7. If the dead person is leas than 5 years old, was "name" born on time?

$$
\begin{aligned}
& \text { On time } \\
& \text { If earlier, how early? }
\end{aligned}
$$

Earlier than expected

Later than expected

Less than one month

1-2 monthe

2 monthe

More than 2 months

8. Did you or anybody in your family seek consultation for "name"?

Yes

Self treatment

No

If yes, from whom?

Doctor
Nurse
B.H.W.
Hakimjee
Dai
Mullah
Shrines
Other

9. Did "name" receive medication one week before death? Yea

No

If yea, what*?

"Alk to see medicine and try to identify

10. What do you think was the cause of death? 
One Form for Each Child Less Than Five Years

Province: District: Town/Village:

Household No: I.D. Number: Age - Years/Months:

Name of Respondent: [*hould be the same person who takes care of the child]

Relation:

1. Was "name" born on time?

On time __ Earlier than
If earlier, how early?
Less than one month
$1-2$ months
2 months
More than 2 months

2. Has "name" ever been breastfed?

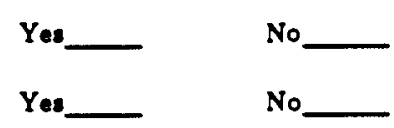

If yes, is "name" atill on breastfeeding now?

Age in months/days:

If no, how old was he/she when stopped?

3. Has "name" ever had bottle milk "powder/animal milk"?

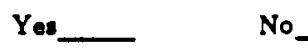

If yes, how old was he/she when started?

Ase in months/days:

4. Has "name" ever had food or fluids other than milk?

Yex

No

If yes, how old wae he/she when started?

Age in months/days:

What food or fluid item were first introduced to him/her?

5. Does "name" have a vaccination card?

Yes

No

If yes, can I see it?

Arailable

Not available 
6. Has "name" ever received a vaccination? If yea, how many times?

Yes

No (Match answer to information on vaccination card]

\begin{tabular}{lcc}
-Scar for TB?: & Nos__ & \\
-Arm Circumference: & $\mathrm{cm}$ \\
-Weight: & $\mathrm{kgm}$ \\
\hline -Height: & $\mathrm{cm}$ \\
\hline
\end{tabular}

Yes

No Name of camp: 
One Form for Every Woman Who Has Delivered During the Last Twelve (12) Months

Province: District: Town/Village:

Household No.: Name of Head of Household:

Woman's Name: [optional]

I.D. Number:

How long ago did the delivery occur? Outcome of delivery: Live birth, Still birth

1. Did you receive medical care during pregnancy? Yes No If yes, from whom?

Doctor, Nurse, BHW, Hakimji, Dai, Pharmacy, Mullah, Other:

Where?

At Home, Hospital, Private Clinic, BHC, Other:

2. Did you receive a vaccination during or before the delivery?

$$
\text { Yes }
$$
No

3. Where did you deliver?

At home, Hospital, Private Clinic, BHC, Other:

4. Who helped you in the delivery?

Doctor, Nurse, BHW, Hakimji, Dai, Pharmacy, Mullah, Other: 